\title{
A bibliometric review of the leadership development field: how we got here, where we are, and where we are headed
}

Article

Accepted Version

Creative Commons: Attribution-Noncommercial-No Derivative Works 4.0

Vogel, B., Reichard, R. J., Batistič, S. and Černe, M. (2021) A bibliometric review of the leadership development field: how we got here, where we are, and where we are headed. The Leadership Quarterly, 32 (5). 101381. ISSN 1048-9843 doi: https://doi.org/10.1016/j.leaqua.2020.101381 Available at https://centaur.reading.ac.uk/89186/

It is advisable to refer to the publisher's version if you intend to cite from the work. See Guidance on citing.

To link to this article DOI: http://dx.doi.org/10.1016/j.leaqua.2020.101381

Publisher: Elsevier

All outputs in CentAUR are protected by Intellectual Property Rights law, including copyright law. Copyright and IPR is retained by the creators or other copyright holders. Terms and conditions for use of this material are defined in the End User Agreement.

www.reading.ac.uk/centaur 
Central Archive at the University of Reading

Reading's research outputs online 
Running Head: BIBLIOMETRIC REVIEW OF LEADERSHIP DEVELOPMENT

\title{
A Bibliometric Review of the Leadership Development Field:
}

How We Got Here, Where We Are, and Where We are Headed

\author{
Bernd Vogel* \\ Henley Business School, University of Reading, Reading, UK \\ email: bernd.vogel@henley.ac.uk \\ Rebecca J. Reichard \\ Division of Behavioral \& Organizational Science, Claremont Graduate University, USA \\ email: becky.reichard@cgu.edu)

\section{Saša Batistič} \\ Department of Human Resource Studies, Tilburg University, The Netherlands \\ email: s.batistic@uvt.nl

\section{Matej Černe} \\ University of Ljubljana, Faculty of Economics, Slovenia \\ email: matej.cerne@ef.uni-lj.si
}

\footnotetext{
* Corresponding author
} 


\begin{abstract}
The development of leaders and leadership is a formative research area and a considerable industry in practice. Existing reviews are often restricted in scope or by subjective inclusion of topics or documents which limits integrative implications for the leader/ship development (LD) field. We address theoretical and methodological limitations by mapping the LD field with a comprehensive, objective, and integrative review. To do so we employed three bibliometric approaches, historiography, document co-citation, bibliographic coupling, and included 2,390 primary and 78,178 secondary documents. We show patterns in the evolution of the LD field, followed by four central observations about the current state and trends in LD. To shift the science and practice of LD we develop tangible suggestions for future research within the three research directions: (1) Pursuing research within the current framing of LD, (2) Striving for frame-breaking LD research, and (3) How We Can Get There - Transforming LD Research.
\end{abstract}

Keywords: leadership development, leader development, bibliometric analysis, review, future research 


\section{A Bibliometric Review of the Leadership Development Field: How We Got Here, Where}

\section{We Are, and Where We are Headed}

Although relatively young compared to the field of leadership scholarship, leader/leadership development (LD) has become a formative area of research and practice (Day \& Dragoni, 2015; Edwards, Elliott, Iszatt-White, \& Schedlitzki, 2013). Whether at the individual (i.e., leader development, or changes in a leader's knowledge, skills, abilities, selfviews, or schemas) or group level (i.e., leadership development, or changes in the collective capacity for leadership in a group; Day, 2000), the field of LD has become a "scholarly discipline separate and distinct from the more traditional approaches to studying leadership" (Day \& Dragoni, 2015, p. 134). From a practitioner perspective, LD has become a multibillion-dollar industry, with organizations spending upwards of \$366 billion annually on developing leadership across levels of the organization (Training Industry, 2019). This popularity is not surprising given LD's impact on building leadership capacity, as highlighted in a meta-analysis on the effectiveness of leadership training (Lacerenza, Reyes, Marlow, Joseph, \& Salas, 2017) and an investigation of return on investment for LD (Avolio, Avey, \& Quisenberry, 2010). Given this growing body of theory, research, and practice, we seek to provide a review of the LD field.

Scholars have conducted informative and impactful reviews of the LD field. However, those reviews have a common limitation - scope. Scholars intentionally and subjectively limited the review scope to accommodate feasibility and focus implications. For instance, in describing his review, Day (2000) states, "the present study does not claim to be exhaustive, rather it will focus on recent practices and research that have been implemented or published typically within the last 5 to 10 years" (p. 582). Other reviews focus on distinct journals (Day, Fleenor, Atwater, Sturm, \& McKee, 2014; Meuser, Gardner, Dinh, Hu, Liden, \& Lord, 2016), a certain level of scientific rigor (Day \& Dragoni, 2015), specific theory (e.g., Edwards et al., 
2013), or unique contexts (e.g., Rhodes \& Brundrett, 2009). Several reviews use arbitrary start dates to include documents (e.g., Day, 2000; Mabey, 2013), or take a broad historic view without clear criteria for inclusion and exclusion of studies and topics (e.g., Avolio \& Chan, 2008). Some focus on elements of the LD process, such as developmental outcomes (Day \& Dragoni, 2015), programs (Fulmer, 1997), or intervention techniques (Ely, Boyce, Nelson, Zaccaro, Hernez-Broome, \& Whyman, 2010). Meta-analytic reviews are limited to quantitative studies and focus on narrow topics such as leadership interventions (Avolio, Reichard, Hannah, Walumbwa, \& Chan, 2009) or leadership training (Lacerenza et al., 2017). Overall prior reviews leave us with fragmented insights and lack of a holistic understanding of the LD field in its entirety. This limitation is touted by critics who stress the LD field's theoretical and methodological fragmentation and point to "little constructive dialogue" between sub-domains (Mabey, 2013, p. 359). They argue, accurately, that this limits theoretical and methodological depth, inclusiveness, and progress of the field of LD, and therefore risks its utility for practice.

In response, we aim to address the limitations of existing reviews and provide a comprehensive and objective picture of the existing LD literature by using bibliometric methodologies. Bibliometric methodologies use broad inclusion criteria spanning time, methods, and sources. Driven by various forms of citation analysis, bibliometric methodologies allow us to discern the relative influence of documents (i.e., journal publication, book, book chapter) and how those documents cluster together in networks. Thus, bibliometric methods illuminate the LD field's underlying intellectual structure and invisible colleges, or the networks of collective communications amongst LD scholars (de Solla Price, 1965; van Raan, 1996; Vogel, 2012). Finally, bibliometric methods reveal patterns and trends in the LD discourse hidden from typical meta-analyses or reviews. The maturity of the LD 
field now allows us to use bibliometric methodologies (Wallin, 2005; Zupic \& Čater, 2015) and to provide a holistic review.

We employ three bibliometric approaches - historiography (Garfield, 2004), document co-citation (Small, 1973), and bibliographic coupling (Kessler, 1963), which help us understand the past, present, and future of the LD field. More specifically, we pursue answers to three specific research questions: (1) How has the knowledge domain of LD evolved? (2) What is the underlying intellectual structure in the knowledge domain of LD? (3) Considering the paths, strengths, and gaps in the structure and evolution of LD research, what are the theoretically and practically relevant future directions for research in LD? In short, the purpose of our paper is to objectively and inclusively examine the LD field in terms of how we got here, where we are, and where we are headed. Although some of our findings will likely be intuitive to seasoned LD scholars, we add a broadened and comprehensive perspective on the evolution, development, and future of the LD field. Thus, this paper is particularly well-suited for burgeoning LD scholars seeking an understanding of the field as well as targeted suggestions for future research.

We begin by providing an overview of the bibliometric methods followed by a detailed description of our sample, initial inclusion criteria, and coding procedure. We then report detailed methods and results for each specific bibliometric study: historiography, document co-citation, and bibliographic coupling. For each bibliometric study, we focus on the 100 most important documents and how they organize into clusters. Finally, integrating across top documents, we examine themes related to the dominant narrative in the LD field: where is the conversation occurring, who are the conversants (Huff, 1999) we are listening to, and what are they discussing. In the discussion section, we provide an interpretation of the findings and tangible suggestions for future research that can strengthen research and the practice of LD. 


\section{Methodology}

Bibliometric methods, although not new (Small, 1973), have only attracted widespread attention in recent years. Because citation analysis underlies bibliometric methods, the growing interest in these methods may be due to the increased availability of online databases with citation data and the development of new analysis software (Zupic \& Čater, 2015). Bibliometric methods complement traditional reviews and meta-analyses as a more objective view of a specific field without constraints (e.g., samples limited to a specific journal or time frame; Zupic \& Čater, 2015). We leverage both three bibliometric methods (historiography document co-citation and bibliographic coupling) and a content analysis of the top documents from those three methods to triangulate the responses to our research questions (cf. Wen, Horlings, van der Zouwen, \& van den Besselaar, 2017). Implementing three different bibliometric methods provides a comprehensive approach to reviewing the LD field by revealing various citation patterns and clustering of related documents. Conducting a content analysis specifically of the top documents further allows an understanding of the discourse in the LD field. Next, we describe the methods employed to identify the documents in our database, the three bibliometric methods, and the content coding.

\section{Primary and Secondary Documents}

Bibliometric methods are driven by various forms of citation analysis among primary and secondary documents. Documents is an inclusive term because it refers to any written source such as journal publications, books, book chapters, etc. More specifically, primary documents are the documents identified from our keyword search that cite other documents; whereas secondary documents were not returned from the keyword search but are cited by the primary documents.

To identify our sample of primary documents, we searched the Web of Science, the most used database in bibliometric research (Batistič \& Kaše, 2015; Zupic \& Čater, 2015). 
We began by searching for the following keywords (using the search on exact matches): "leadership development," "leader development," "management development," "manager development," "management training," and "manager training." We chose these search terms to capture both the contemporary (leadership; development) and earlier nomenclature (management; training), allowing a comprehensive set of primary documents across time. From there, we refined our search to the following categories: economics, education scientific disciplines, management, business, education, educational research, multidisciplinary sciences, psychology applied, psychology multidisciplinary, psychology social, psychology, and education special. This approach returned 2,390 primary documents and 78,718 secondary (i.e., cited) documents. Arguably, this is a much larger sample than has been included in prior reviews.

\section{Bibliometric Methods}

Although a comprehensive description of the three bibliometric methods is beyond the scope of this review, we provide an overview of each method in Table 1, including the focal point, temporal focus, uniqueness, methodological mechanisms, and indicator of document strength. Based on citation relationships and visualized in a figure, each method (a) provides information about the strength of documents and (b) maps clusters of relationships among documents. In the respective methods sections, we elaborate on the various approaches to calculating document strength for each method and use the term weight interchangeably. The determination of what constitutes a 'top document' is dependent on document strength, and we focus our interpretation on those documents. Visually, document strength is displayed based on the size of the circle, with larger circles indicating more highly weighted or top documents based on citations. Citation relationships are visually displayed using different color circles to depict clustered, or related documents, and lines and distance to depict the strength or closeness of those document interrelationships. 


\section{--- INSERT TABLE 1 ABOUT HERE ---}

What differs across the three bibliometric methods is how each examines the citation relationships among primary and/or secondary documents. Briefly, historiography maps the chronology of primary documents citing other primary documents, thus tracing how ideas move through time from document to document. For example, the idea of assessing the developmental components of managerial jobs was discussed by McCauley et al. in 1994 and later cited by other primary documents, such as Day's (2000) review on approaches to LD and McCall's (2010) paper on learning leadership from experience. Thus, historiography shows the development of the LD field over time and displays a chronological ordering of its most important documents, along with their citation relations (Garfield, 2004; van Eck \& Waltman, 2014a). Document co-citation focuses on the overlap of the bibliographies of primary documents. In other words, the emphasis is on which and how often two secondary documents are cited together within primary documents. For example, primary documents returned from our keyword search frequently co-cited the secondary document of Day (2000) along with various other secondary documents (e.g., Lord et al., 2005). By examining which and how often secondary documents are co-cited, document co-citation explores relationships and interactions between different researchers, revealing a field's intellectual traditions and roots (Vogel, 2012). Finally, whereas document co-citation emphasizes the frequency with which secondary (cited) documents are cited together, bibliographic coupling focuses on the primary (citing) documents that cite the same secondary documents. Thus, bibliographic coupling identifies emergent topics and potential future developments in the literature (Van Raan, 2005). In this way, the three bibliometric techniques offer different insights into how knowledge is situated and structured within the LD field.

\section{Content Coding of the Top 100 Documents}


Finally, we sought to go beyond the structural information or knowledge maps yielded from the bibliometric methods. Thus, we content coded the top 100 documents from each of the three methods to allow for rich descriptions of the discourse in the LD field. Again, top documents are those with the largest citation strength or weight. In total, we coded 247 documents because some appeared in the top 100 documents of more than one of our bibliometric studies.

Seven graduate students (four doctoral, three masters) in organizational psychology were trained to follow a comprehensive coding reference guide under the supervision of two authors. Coding categories included document basics (e.g., year of publication, source of publication, basic vs. applied), content (e.g., leadership domain, core theories), methods (e.g., conceptual vs. empirical, analysis technique, level of analysis), and process elements (e.g., developmental antecedents and outcomes). ${ }^{1}$ Two independent coders yielded an average percentage of agreement of $82.9 \% .^{2}$ A third coder resolved discrepancies by independently examining the source document. In cases where multiple coded responses emerged (e.g., analysis technique), we included all elements (e.g., regression, ANOVA) identified by the coders. We include a description of findings related to coding categories throughout the results sections of the three studies and conclude the results by integrating thematic coding findings of the top documents across studies.

\section{Study 1 Historiography}

\section{Historiography: Methods and Analysis}

We began our analysis using historiography, a bibliometric approach aimed at capturing the evolution and dynamics of a field (Garfield, 2004; van Eck \& Waltman, 2014a).

\footnotetext{
${ }^{1}$ For complete coding descriptions, raw coding, and frequency tables contact the corresponding author.

${ }^{2} 237$ of the 247 studies were coded by two coders with the remaining 10 being coded by one coder.
} 
Historiography considers the relationships between only the primary documents, or those documents in our database identified through the keyword search. Let's take two primary documents in our database returned from our keyword search - document A and B. If primary document A (e.g., Day, 2000) cites primary document B (e.g., McCauley et al., 1994), then a linkage is formed which supposes knowledge flow and topic similarity between the two primary documents (Liu et al., 2013). To cite an older document, document A must be newer than document B; thus, historiography captures the evolution of a certain topic (van Eck \& Waltman, 2014a). The more citations a particular primary document accumulates, the more "core" (or important) it is thought to be because the knowledge is flowing from that primary document to many other later primary documents. Changes in the citation of key documents illuminate how central topics change over time. As a result, historiography provides an understanding of dominant paradigms and their shifts (Garfield, Pudovkin, \& Istomin, 2003).

Using the software tool CitNetExplorer (van Eck \& Waltman, 2014a), we included our sample of 2,390 primary documents based on previously described search criteria. CitNetExplorer highlights the most important primary documents in two ways. First, it identifies core documents, those that have citation relations with at least ten other core documents (Van Eck \& Waltman, 2014a). Garfield et al. (2003) and Batistič and van der Laken (2019) note that studies typically visualize the 5\% most cited (core) documents. Aligned with this recommendation and to maintain a clear visualization, we show a network of the top 100 core documents (approximately $4.2 \%$ of all documents). Second, CitNetExplorer performed a transitive reduction of the citation network. This reduction considers only essential relations, defined as the sole connection between two documents. CitNetExplorer then visualizes the resulting network with publication year on the vertical axis and closeness between documents on the horizontal axis (see van Eck, Waltman, Dekker, \& van den Berg, 2010 for a more technical explanation). 


\section{Historiography: Results}

To begin to understand the evolution of the LD field and how knowledge has been passed down over time, we observe that the top 100 documents formed 10 clusters, or groupings of interrelated documents. However, Figure 1 shows that four clusters (Cluster 1, blue; Cluster 2, orange; Cluster 3, yellow; Cluster 4, green) form the main evolutionary path of LD, with Cluster 1 (blue) being overall dominant and the other three clusters eventually intertwining in one main debate. Therefore, we focus our interpretation of results on identifying key themes within the dominant cluster 1 (blue) and tracking the evolution of those themes.

---Insert Figure 1 here---

Cluster 1 (blue) is the largest cluster, housing most of the core documents ( $n=66)$. The historical foundations of cluster 1 are themes related to the practice of LD in organizations. Specifically, early themes relate to individuals learning from experience (McCall, 2004; 2010), with McCauley, Ruderman, Ohlott, and Morrow's (1994) Journal of Applied Psychology paper on assessing the developmental components of managerial jobs serving as the theoretical origin of this concept. Building from this perspective, this cluster includes several more recent empirical studies on learning from experience (DeRue \& Wellman, 2009; Dragoni, Tesluk, Russel, \& Oh, 2009). Other practice-oriented themes also emerged with earlier studies on 360-degree feedback (e.g., Atwater \& Waldman, 1998; Maurer, Barbeite, \& Mitchell, 2002), leadership skills and competencies (e.g., Hollenbeck, McCall, \& Silzer, 2006; Mumford, Marks, Connelly, Zaccaro, \& Reiter-Palmon, 2000), and executive coaching (Boyatzis, Smith, \& Blaize, 2006; Feldman \& Lankau, 2005). Notably, these all show the historic premium LD research has placed on understanding practical LD topics in organizational contexts. 
Another theme that emerges within the first cluster is the evolutionary shift from practice-oriented origins toward theory development, particularly represented by authentic leadership development. In addition to the desire for a theory of LD, the origins of authentic leadership development grew out of practical challenges related to ethical leadership scandals in the early 2000s and the popularization of the topic from practitioners (e.g., George, Sims, McClean, \& Mayer, 2007). Much of this research can be traced to the 2005 special issue of The Leadership Quarterly (Avolio \& Gardner, 2005; Cooper, Scandura, \& Schriesheim, 2005; Gardner, Avolio, Luthans, May, \& Walumbwa, 2005; Shamir \& Eilam, 2005), which was the culmination of a leadership summit hosted by the University of Nebraska and the Gallup Organization in 2004. This theme continues in the next few years with a measure validation paper by Walumbwa et al. (2008) and a review paper by Avolio (2007). Building on the work of authentic leadership development, the narrative or life-stories approach to understanding LD also emerges as a theme in cluster 1 (Ligon, Hunter, \& Mumford, 2008; Shamir \& Eilam, 2005; Sinclair, 2009).

In summary, we make two main observations from the results of the historiography and the journey and shifts of LD knowledge over time. First, the core documents over time form one main grouping (cluster 1, blue). Other work (clusters) is only tangentially connected. Thus, the knowledge in the LD field has been passed down through one main narrative. Within the main narrative, we see that among other themes, the LD field grew out of real practical challenges and has more recently shifted toward substantial theory development. Stopping with only the historiography would limit our understanding of the intellectual structure of the LD field; thus, we next turn to document co-citation. 


\section{Study 2 Document Co-citation}

\section{Document Co-citation: Methods and Analysis}

Whereas historiography emphasizes how primary documents cite other primary documents, document co-citation focuses on how primary documents cite pairs of secondary documents together, indicating semantic similarity. Two important outcomes of the document co-citation are the degree of co-citation strength and the visualization of the clustering of the co-cited secondary documents into "invisible colleges" or groups of scholars who communicate with each other regarding a shared interest (de Solla Price, 1965; van Raan, 1996; Vogel, 2012).

First, as an indicator of importance, co-citation strength refers to the frequency with which two secondary documents are co-cited by primary documents. The top 100 documents ranged in co-citation strength from 88 to 1002 , with an average strength of 235 ( $S D=131.8)$. The higher a document's co-citation strength, the more likely it is semantically related to other documents, and the more important is its role in the field (Small, 1973). For example, primary documents co-cited Day (2000) 1002 times with 99 different secondary documents. So, Day's (2000) document formed 99 dyads (e.g., the pair Day (2000) and Bass (1985)), which suggests that every dyad on average appeared 10.12 times together with Day (2000) in the primary documents. The underlying assumption fueling this analysis is that when two secondary documents are co-cited (i.e., referred to in the same primary document), they share content similarities (Small, 1973). Document co-citation is a dynamic measure that changes through time as older documents accumulate more citations (Batistič, Černe, \& Vogel, 2017).

In addition to indicating co-citation strength, document co-citation visualizes clusters depicting the relationships among the co-cited documents. Due to a large number of unique secondary documents $(78,178)$, we only included secondary documents that exceeded a citation threshold of five $(n=2,156)$. This inclusion criterion limited the number of secondary 
documents to a manageable size and addressed computational power limitations from a large sample. We used the software tool, VOSviewer (van Eck \& Waltman, 2014b), for the cocitation analysis. This software normalizes the data via association-strength normalization (van Eck \& Waltman, 2014b), which acknowledges that some secondary documents are more popular with more connections than less popular documents. The program then arranges the secondary documents in a two-dimensional space such that strongly related nodes are located close to each other while weakly related nodes are further apart. The program then assigns a document only to one cluster (i.e., a set of closely related nodes). Finally, to visualize a cocitation network, VOSviewer uses colors to indicate the cluster assigned to a secondary document.

\section{Document Co-Citation: Results}

We present our results, by first providing an overview of the coding categories of the 100 most important documents in the document co-citation analysis (i.e., those with the highest co-citation strength). Then, we describe the three clusters that emerged in the analysis.

Top 100 documents. Table 2 and Figure 2 summarize and visualize the 100 most important documents from the co-citation analysis. Of the 100 most co-cited documents, 35 were books, and nearly half (47) were published between 2001-2010. Dominant journal outlets included The Leadership Quarterly (21) and the Journal of Applied Psychology (10).

Of the 100 top documents, 41 were theoretical, 13 were review papers, and nine were metaanalyses. Forty-four documents focused on transformational leadership, 33 focused specifically on LD, and 23 were on topics other than leadership (e.g., learning theory or methodology). The majority of the top 100 documents emphasized multiple levels of analysis (61), though the majority were at the micro-level (41).

---Insert Table 2 and Figure 2 here--- 
The document with by far the largest co-citation strength $(1,002)$ was Day $(2000)$, a review paper on leadership development in context published in The Leadership Quarterly. We attribute the importance of this document to at least two major factors - originality in conceptualization and linkage to practice. Day distinguished for the first time between leader development (i.e., development of individual-level intrapersonal skills and abilities or human capital) and leadership development (i.e., developing a network of relationships facilitating the social process of leadership or social capital). Tying to the practice-oriented roots of the LD field observed in the historiography, he also reviews the most common practical approaches to developing leadership, including 360-degree feedback, executive coaching, mentoring, networking, job assignments, and action learning. The centrality of Day's paper supports its lasting influence as a review of the field and as a source of clarification for the difference between leader development and leadership development.

Other dominant documents focused on leader identity, authentic leadership development, and leadership (see Table 3 for a description of the top 5 papers by cluster). Specifically, the Lord and Hall (2005) article on leader identity theory published in The Leadership Quarterly has a large co-citation strength (632). The authors advance a theory of identity development in which an individual develops from novice to intermediate to an expert leader associated with cognitive changes in their conceptualization of leadership. The prominence of this document emphasizes the influence of identity theory on the overall LD field, a theme we return to later. Avolio and Gardner's (2005) theoretical paper on authentic leadership development, similarly published in The Leadership Quarterly, also had a large cocitation strength (448) and focused specifically on LD. Beyond works on the development of leaders, other important documents include Bass' (1985) (717) and Burns' (1978) (489) classic books on leadership, indicating the strong role these origin leadership perspectives have on the LD field. 
Document Co-Citation Clusters. Overall, the document co-citation analysis revealed three clusters or knowledge domains. Documents in cluster 1 (red; 9,708) included the highest overall number of citations, followed by cluster 3 (blue; 7,582), and then cluster 2 (green; 6,257). Clusters 1 and 2 are connected by cluster 3, particularly via the Day (2000) and Lord and Hall (2005) articles previously discussed. We now turn to a description of each cluster.

Co-citation Cluster 1 (red). Leadership styles, seminal and theoretical work. As the largest and most influential cluster, 40 of the top 100 documents compose cluster 1 (red). Most of these documents focus on leadership styles, particularly transformational and transactional leadership, charismatic leadership, and authentic leadership development. Overall, cluster 1 has a limited focus on development, with $70 \%$ of the studies emphasizing leadership more broadly rather than the development of leadership capacity. Almost $30 \%$ of the documents were published in The Leadership Quarterly. Documents tended to focus on basic rather than applied research (87.5\%) and were theoretical (42\%). Finally, most documents emphasized multiple levels of analysis (75\%), including micro, meso, and macro levels $(35 \%)$. However, it is important to note that the most advanced multilevel work is theoretical and not empirical, indicating that the multilevel perspective better reflects the field's aspiration than reality.

Two separate subgroupings emerged in cluster 1 . The first subgroup includes seminal books on transformational and transactional leadership by Burns (1978) and Bass (1985), as well as classic papers on charismatic leadership (Shamir, House, \& Arthur, 1993) and leadermember exchange (Graen \& Uhl-Bien, 1995). This finding seems to represent the origins of the LD field in traditional leadership research with a straightforward focus on developing leaders who enact those styles or behaviors. A good example of this is Dvir, Eden, Avolio, and Shamir (2002), who report the effects of training transformational leadership in a true 
field experiment with the Israeli Defense Force. In contrast, the second subgroup in cluster 1 shift toward a more sophisticated understanding of the LD process (i.e., personal and contextual antecedents, mediators, moderators, and outcomes of LD). This second subgroup includes the foundational theoretical papers underpinning authentic leadership development (e.g., Avolio \& Gardner, 2005; Avolio, Gardner, Walumbwa, Luthans, \& May, 2004).

Co-citation Cluster 2 (green): Learning and elements of the LD process. The 33 publications in cluster 2 (green) tend to be older, with 33\% published between 1981-1990, and $67 \%$ before 2000 . Overall, these documents had weaker co-citation strength, as reflected by smaller circles in the figure. Many were books (48\%) and focused on topics other than leadership, yet informed leadership development (60\%), such as learning theory and goalsetting theory. In contrast to other clusters, no documents were published in The Leadership Quarterly, again reiterating the non-leadership focus of this cluster. Instead, the majority of empirical and conceptual articles were primarily published in other highly ranked, mainstream journals (e.g., Journal of Applied Psychology).

Specifically, classic treatises on motivation and learning were also included, such as Bandura's $(1977,1986,1997)$ books on social cognitive theory and self-efficacy, Kolb's (1984) book on experiential learning, Locke and Latham's (1990) book on goal-setting, and Dweck's (1986; Dweck \& Leggett, 1988) research on motivation and goal orientation. Cumulatively, $32 \%$ of the documents focused on learning theory, and $41 \%$ were situated in the field of Developmental Psychology. Finally, several documents in cluster 2 emphasized training effectiveness (e.g., Baldwin \& Ford, 1988; Noe, 1986), including meta-analyses by Collins and Holton III (2004) and Burke and Day (1986).

Culminating the focus on learning and motivation, the dominant documents in cluster 2 focus on learning leadership via experience. Specifically, DeRue and Wellman (2009) empirically examined 225 on-the-job experiences of 60 managers and found that 
developmental challenges have diminishing returns on skill development unless feedback was accessible. McCauley, Ruderman, Ohlott, and Morrow (1994) developed and validated a survey to assess developmental challenges. McCall, Lombardo, and Morrison (1988) described how leaders learn from hardships and work assignments.

\section{Co-citation Cluster 3 (blue): Theoretical frameworks and intra-person learning}

mechanisms. As the smallest cluster, cluster 3 (blue) includes 27 documents, $70 \%$ of which were published between 2001-2010. Twenty-five of the documents were journal articles, 12 of which published in The Leadership Quarterly. Most documents focus on basic rather than applied research (89\%) and on multiple levels of analysis (63\%); however, the multilevel work is again theoretical and not empirical. Multi-level work includes the following documents focused on organizations and systems perspectives: Uhl-Bien, Marin, and McKelvey's (2007) paper on complexity leadership, Uhl-Bien's (2006) paper on relational leadership, and Mumford, Campion, and Morgeson's (2007) paper on leadership skills strataplex.

Day was featured prominently in this cluster, authoring five of the 11 most co-cited papers, including the document with the highest co-citation strength (Day, 2000). This seminal review paper is also a key boundary spanner that connects documents across all three clusters. Other notable reviews include a meta-analysis of leadership intervention research (Avolio et al., 2009), a meta-analysis on personality and leadership (Judge, Bono, Ilies, \& Gerhardt, 2002), and a review on 25 years LD research at The Leadership Quarterly (Day et al., 2014).

Leader identity is a dominant theme in cluster 3. Notable documents include Lord's work (Lord \& Hall, 2005; Lord, Foti, \& DeVader, 1984), Day and Harrison’s (2007; Day, Harrison, \& Halpin, 2009) integrative theory, DeRue and Ashford's (2010) co-construction of leader identity, Hogg's (2001) social identity theory of leadership, and van Knippenberg, van 
Knippenberg, De Cremer, and Hogg's (2004) review on leadership, self, and identity. This dominant theme indicates that leader identity and its development is a key topic in the LD field.

A final component of this cluster represented studies on women's leadership development (e.g., Eagly \& Karau, 2002; Ely, Ibarra, \& Kolb, 2011). However, it is noteworthy that these documents are not connected with the primary cluster. This disconnect of women's leadership aligns with the findings of Lyness and Grotto (2018). They state that between the Academy of Management Journal, Journal of Applied Psychology, Journal of Management, and The Leadership Quarterly, on average, only about 7\% of published leadership articles mention women or gender-based consequences. We also found that women were first authors on only 15 of the top 100 documents in the co-citation analysis and only three of those documents included gender as a main focus.

Overall, we learn from the document co-citation analysis that the LD field is heavily informed by seminal research on leadership, motivation, and learning and has evolved into a more explicit focus on development, particularly intrapersonal processes such as identity development. Whereas the document co-citation results allow us to understand the intellectual structure of the LD field, it has a more historical focus. Thus, we turn to bibliographic coupling, which is future-oriented identifying trends in the LD field.

\section{Study 3 Bibliographic Coupling}

\section{Bibliographic Coupling: Methods and Analysis}

Bibliographic coupling provides analytical implications beyond document co-citation by providing a current view of the field. Document co-citation focuses on the citation of secondary documents, thus requiring the accumulation of citations over time, inherently situating the results of this method in the past. Instead bibliographic coupling focuses on the primary documents and what secondary documents they are citing, thus situated in the 
present. Because the primary documents that include citations are de facto more recent than the cited secondary papers, the coupling analysis helps detect trending priorities. More specifically, the purpose of bibliographic coupling analysis is to explore documents considered "coupled," or if and how primary documents' bibliographies overlap. The analysis investigates if two primary documents have at least one reference (i.e., secondary document) in common (Kessler, 1963). Hence, the focus of the bibliographic coupling is the citing document (i.e., primary documents), rather than the documents they cite (i.e., secondary documents).

The more the bibliographies of two primary documents overlap, the larger the coupling strength, or document weight. Take primary document A and B, which both cite secondary documents $\mathrm{C}, \mathrm{D}$, and $\mathrm{E}$. The coupling strength of primary documents $\mathrm{A}$ and $\mathrm{B}$ equals three, the co-occurrence of secondary documents in their reference lists. In our data set, for instance, the primary document by Day (2000) has a document weight of 275 (i.e., coupling strength) and appears in a coupling relationship with 89 other primary documents (e.g., Galli \& Muller-Stewens, 2012). These 89 pairs and Day (2000) cite an average of 3.08 references together.

In the present study, we used the same dataset for the bibliographic coupling as the other two bibliometric methods. Of the 2,390 total primary documents, we again applied a cutoff point of five as the minimum number of primary document citations ( $n=944)$. We again visualized the data using the VOSviewer program and the same procedures employed in cocitation analysis.

\section{Bibliographic Coupling: Results}

We present the results of the bibliographic coupling by first providing an overview of the 100 most important documents that emerged in the analysis. Then, we provide an overview of each emergent cluster. 
Top 100 documents. We summarized and visualized the 100 documents with the highest coupling strength in Table 4 and Figure 3. Of those 100 documents, 98 were journal publications, 50 of which were published in The Leadership Quarterly, indicating the predominance of this outlet in the trending LD field. Most documents were published between 2011-2015 (59), focused on LD (61), were basic (rather than applied) research (53), and emphasized the micro-level of analysis (65). Dominant theories cited include self and learning theories, whereas key theoretical domains were organizational, social, developmental, and cognitive psychology.

---Insert Table 4 and Figure 3 here---

The document with the highest coupling strength (700) was Avolio and Chan's (2008) book chapter reviewing 80 years of research and theory on LD, published in the International Review of Industrial and Organizational Psychology. The next highest, with a strength of 496, was Day and Dragoni's (2015) article, published in the Annual Review of Organizational Psychology and Organizational Behavior. This paper provided a framework for conceptualizing proximal and distal leader development and leadership development outcomes. Thus, it expands on Day's (2000) leader development versus leadership development distinction to include the element of time in the LD process.

Bibliographic Coupling Clusters. Regarding the overall structure, the coupling analysis returned four clusters. Cluster $1(11,409)$ had the highest number of citations, followed by cluster $2(9,961)$, cluster $3(3,041)$, and then cluster 4 (239). Three critical papers broker between clusters: Avolio and Chan (2008), Epitropaki, Kark, Mainemelis, and Lord (2017), and Klimoski and Amos (2012). Next, we provide a brief overview of the clusters.

Coupling Cluster 1 (red): Authentic leadership development and empirical work on (non-developmental) leadership. The 43 documents in cluster 1 are primarily conceptual publications with an emphasis on authentic leadership development. Avolio is an author on 
five of the top six publications in this cluster (see Table 5 for a description of the top five weighted papers by cluster), underscoring his role in the popularization of authentic leadership development. Other documents focus on a range of specific leadership (nondevelopment) topics, including theory integration for leader-follower dynamics, social distance, charisma, and the meaning of context. The most important documents were primarily published in mainstream leadership outlets (e.g., The Leadership Quarterly, Journal of Management, Journal of Organizational Behavior).

---Insert Table 5 here---

\section{Coupling Cluster 2 (green): Empirical LD research and longitudinal and multi-level}

work. Two noteworthy trends emerge from the 41 documents in cluster 2 . First, documents are largely empirical. Nearly half (46\%) are quantitative and focus on LD (83\%). Seventythree percent of the documents focus on the micro-level of analysis, and $46 \%$ emphasized a longitudinal perspective (e.g., Murphy \& Johnson, 2011; Day, 2011). Second, several key review papers (e.g., see Table 4; Day \& Dragoni, 2015; Day et al., 2014) dominate this cluster. Publications mostly appear in high-impact journals (e.g., The Leadership Quarterly, Journal of Applied Psychology, Academy of Management Learning \& Education). Day had five first-authored publications in cluster 2 , many with high coupling strength.

Coupling Cluster 3 (blue): Alternative and critical approaches to LD. With a total of only 15 documents, cluster 3 is a mix of more mainstream and alternative approaches to LD and leadership. The small circles reflect weaker weightings, with limited exceptions (see Bolden, 2011). Overall, the identity paper by Epitropaki et al. (2017) has the highest coupling strength (386) in cluster 3 and functions as a bridge to the other two traditional clusters. The alternative works in this cluster include challenges to functional approaches towards LD and leadership. Documents tend to be theoretical or a review of the literature and address topics such as identity, schema or meanings, alternative types of learning/development interventions, 
and critical approaches to LD at both the micro and macro levels. In line with this theme, this cluster has the highest share of qualitative studies (4), which tend to utilize content analysis. The top documents appear in a variety of journals, including those with international connections, such as Leadership, Management Learning, and International Journal of Management Reviews. The Leadership Quarterly remains the most common outlet (66\%).

Cluster 4 (yellow): Single article on leader identity development. The fourth cluster consists of just one publication, Lord and Hall's (2005) theoretical article on developing leader identity. With a coupling strength of 239 , it is the $38^{\text {th }}$ (of 100) most important document in the bibliographic coupling. This linking document again emphasizes the ongoing relevance of work on leader identity in the LD field.

In summary, the results of the bibliographic coupling provide a lens on the current and trending direction of the LD field. We observed the dominance of The Leadership Quarterly as a key publication outlet. Of the three clusters, one emphasized authentic leadership development and particularly Avolio's work. A second emphasized empirical, longitudinal, and multi-level work emphasized by Day. A third cluster provided alternative and critical approaches to LD, including international authors and sources. Taken together, these findings inform the current and trending perspectives on the LD field. Next, we further examine the content of the top documents that emerged from the bibliometric methods.

\section{Content Analysis: Examining the Past and Trending Conversation in the LD Field}

To conclude our analysis, we examine major attributes of the top documents in the LD field and make comparisons between past (top 100 co-citation studies) and trending (top 100 bibliographic coupling studies) documents where notable. We build on Huff's (1999) idea that researchers need to understand what she calls the conversation in a field of study. We seek to explore the conversation of the LD field overall with the following questions: Where is the conversation happening? Who are the conversants? What are the main topics of conversation? 


\section{Where is the $\mathbf{L D}$ conversation happening?}

To understand where the dominant conversation in the LD field has been occurring, we coded the type of publication (i.e., book, book chapter, or journal). Whereas past top documents included a larger number of books (33), the current top documents were nearly all journal articles (98). The Leadership Quarterly was the dominant journal across both past (21) and current (50) top documents. Other dominant journals included Journal of Applied Psychology, Academy of Management Learning \& Education, Leadership, Personnel Psychology, Academy of Management Review, Journal of Management, and Journal of Organizational Behavior.

\section{Who are the key conversants in the LD field?}

We examined the frequencies of the first author of the top 100 documents to examine whose voices dominate the LD field. Based on the frequency of top documents, we found that the main conversants were Avolio, Day, Bass, and McCall. Avolio, in particular, was an author on 19 of the top documents, including being the first author on 10 of those. Day was the first author on nine top documents. Bass was first author on eight, while McCall was the first author on six documents and co-author on one other.

The documents by each of these authors also tended to cluster together in the analysis. For example, in the document co-citation, we see that almost all of Bass's documents are in cluster 1, Day's in cluster 3, and ten of Avolio's documents in cluster 1 (with five in cluster 3). Similarly, in the bibliographic coupling analysis, all five of Day's top documents were in cluster 2, and five of Avolio's documents were in cluster 1 (with 2 in cluster 2). We also observed that the bibliographic coupling top documents, which are more recent and forwardlooking, had a greater range of first authors (e.g., Dragoni, Waldman, DeRue, and Mabey). That means in the present we listen to a broader range of conversants. However, it is worth noting that among top conversants, most are Caucasian males based in the United States. 


\section{What is the content of the conversation among the dominant documents in the LD field?}

Finally, we sought to better understand the topics, theories, antecedents, and outcomes of LD that are dominating the conversation in the field. To begin, our coding determined whether documents focused on leadership, LD, or non-leadership (e.g., learning theory) topics. We found that documents tended to cluster based on their emphasis related to the overall topic area. In the co-citation analysis, three emergent clusters had a differing emphasis on aspects of LD. One focused substantially on seminal, conceptual leadership styles as opposed to LD. A second clustered together self-regulation, learning, and experience, so documents that support the concept of LD. And a third explicitly grouped largely theoretical LD research specifying intrapersonal development including identity. In contrast, the bibliographic coupling results, which reflect more recent and forward-looking documents, suggest the main emphasis of the conversation has shifted substantially to explicitly focus on various aspects of LD as opposed to leadership or non-leadership. Next, we sought to understand what antecedents and outcomes the LD conversation emphasized.

Antecedents of LD. A key topic of the LD conversation is situated around contextual or personal antecedents (i.e., mechanism, mode, source) to LD. Contextual antecedents refer to those mechanisms or sources of learning that are external to the developing individual, group, or collective. Across the top documents, we observed that authors repeatedly discussed various types of organizational interventions like training, feedback, coaching, reflection, action learning (e.g., Janson, 2008), and mentoring (e.g., Lester, Hannah, Harms, Vogelgesang, \& Avolio, 2011). Authors of top documents also emphasized more informal and experiential contextual antecedents to LD like learning on the job, challenging developmental assignments (e.g., Courtright, Colbert, \& Choi, 2014), and personal history, life experiences, trigger events, and adversity (e.g., Avolio \& Chan, 2008; Gardner et al., 2005). Unique to the top recent and forward-looking studies, we found authors mentioning less traditional 
contextual antecedents to LD, such as play (Kark, 2011) and improvisational theater (Gagnon, Vough, \& Nickerson, 2012). To a lesser extent, authors of top documents discussed the broader organizational environment, culture, and support as antecedents to LD.

Next, we examine the personal antecedents of LD for the top 100 past and current documents. Personal antecedents refer to those mechanisms or sources of development that are internal to the developing individual or collective. Across the top documents, we observed three main categories of personal antecedents ordered from most to least frequent. First, the authors discussed self-related antecedents, including identity, self-efficacy, self-awareness, and self-regulation (e.g., Avolio \& Gardner, 2005; Lord \& Hall, 2005). A second category included learning attitudes and motivation, such as learning goal orientation, feedbackseeking, and motivation to lead (e.g., Chan \& Drasgow, 2001). Less prominent personal antecedents to LD include personality/individual attributes such as openness, affect, cognitive ability, and implicit theories. One top document by Avolio and Hannah (2008) provides a framework for conceptualizing personal antecedents to LD, referred to as developmental readiness, which consists of an individual's motivation and ability to develop. Taken together, we observed a wide variety of contextual and personal antecedents discussed in top documents, which helps us understand the mechanisms, modes, and sources of LD.

Developmental Outcomes of LD. In addition to the antecedents to LD, we observe what the most frequent topics of conversations are across the top documents from the document co-citation and bibliographic coupling analysis regarding developmental outcomes of LD (i.e., individual or collective).

Individual developmental outcomes refer to developments or changes at the individual level (i.e., the micro-level). Across top documents, a heavy emphasis on individual developmental outcomes for leadership competencies, knowledge, skills, behaviors, abilities, and self-related outcomes emerged. A variety of skills were targets of development including 
task, social/interpersonal/team, emotional, problem-solving, cognitive, and critical thinking skills. In addition to general leadership behaviors, the development of transformational leadership was a frequently targeted individual outcome (e.g., Dvir et al., 2002). Finally, selfrelated outcomes included identity, self-awareness, self-efficacy, self-esteem/self-worth, and self-regulation. Although developing followers and their capabilities were not common themes, it did emerge in a limited number of past top documents, pointing to some interest in understanding leadership as a process involving both managers and employees.

Although the majority of documents focus on individual outcomes, a small body of work exists that explores collective developmental outcomes, those at the group or organization level (i.e., meso- or macro-level). The most frequently mentioned include effectiveness (e.g., follower performance, organizational performance) and team-related outcomes, such as team learning, process, efficacy, creativity, safety, communication, back-up behavior, psychological safety, shared mental models, and transactive memory. The most influential past document (Day, 2000) addresses a broad range of collective, yet mostly teamlevel outcomes (e.g., teamwork, networks, shared vision, common values, interpersonal competence). However, the discussions of collective outcomes we found tended to be theoretical, and a true understanding of what develops/changes on a collective level seems to be an empirically neglected area within the field of LD.

Detrimental aspects of LD. Lastly, we were curious as to what scholars are saying about the detrimental aspects of LD for the learner, team, organization, or society. Although we identify examples of detrimental aspects of LD, it is noteworthy that this is a small and overlooked area of investigation. The conversation in the LD field seems to lack a balanced and holistic perspective, given the range of potential positive and negative evaluations and emotional experiences across LD processes and outcomes. 
Only 9 of the top 100 documents of the past (co-citation) mentioned detrimental aspects of LD. For example, Burns (1978) makes a general reference to the darker side of leadership, and others point to the dysfunctional effects of charisma (Avolio, 2005). Kluger and DeNisi (1996) acknowledge the possible dysfunctional effects of feedback interventions on performance, whereas Kanfer and Ackerman (1989) discuss contingencies in learning where goal assignments can negatively influence performance. Finally, authors acknowledge that developmental trajectories are not always positive and linear (Day \& Sin, 2011) and point to the possible abuse of power that can result from being accepted as a leader (Hogg, 2001).

By contrast, a few more of the top recent and forward-looking documents referred to detrimental aspects of LD. Examples include perception of problematic LD practices in specific industries (i.e., healthcare, McAlearney, 2006) and negative effects of too much developmental challenge (DeRue \& Wellman, 2009), including emotional exhaustion (Courtright, Colbert, \& Choi, 2014) and unpleasant feelings (Dong, Seo, \& Bartol, 2014). Top more recent and forward-looking documents also included research on negative or non-linear developmental trajectories (Day \& Sin, 2011) and the negative impact of gender differences, including how gender biases interfere with identity work in developing women leaders (Ely, Ibarra, \& Kolb, 2011) and gendered access to early life and leadership experiences (Li, Arvey, \& Song, 2011). Finally, other detrimental outcomes discussed included the negative impact of misalignment between the authentic self and organizational goals (Berkovich, 2014) or lack of appreciation for diversity of people. Taken together, we observed a limited dialogue around detrimental aspects of LD.

\section{Discussion}

The burgeoning LD field is fragmented and in need of a comprehensive, holistic review. The current bibliometric study circumvents many of the challenges encountered by prior LD reviews and meta-analyses. These traditional methods mirror some of the 
fragmentation in the LD field and are often focused, for instance, on a limited aspect of the field, such as the effectiveness of leadership training (Lacerenza et al., 2017), coaching (Feldman \& Lankau, 2005), or individual and team level outcomes of LD (Day \& Dragoni, 2015), or include a limited set of journals or specific type of studies or limited review timeframe. Such theoretical compartmentalization is justifiable for reasons of parsimony and to create scientific progress (Glynn \& Raffaelli, 2010). However, limiting the inclusion of documents constrains our ability to fully understand previous and current theoretical developments of the LD field at large and hampers our capability to guide future research.

To overcome the limitations of existing reviews, we utilized three bibliometric approaches (historiography, document co-citation, and bibliographic coupling; Zupic \& Čater, 2015) to map the evolution, current state, and future directions of the LD field. The comprehensive and inclusive nature of our review shows in the following two aspects. First, our studies allowed inclusivity across time. Documents in each of the top 100 across the three studies (247 in total) ranged in date from 1967 (Fiedler) to 2017 (Epitropaki et al.) with an average publication date of 2005 (historiography), 1999 (document co-citation), and 2011 (bibliographic coupling). As such, some of the essential documents for explaining the structure of the field of LD (e.g., Latham \& Frayne, 1989) originated before the focal period chosen in other reviews (Day, 2000; Day et al., 2014; Meuser et al., 2016). Second, bibliometric methods allowed us to be inclusive across sources. We observed a broad range of influential documents that may not necessarily feature in existing reviews, including books, book chapters, and journal articles.

Given this inclusivity, we set out to contribute to the LD literature in three ways. The relevant primary and secondary documents sourced via bibliometric methods were based on both the strength of the document and the relationships among documents. This approach allowed us to move beyond the limited scope of narrow inclusion criteria and subjectivity in 
selecting documents, as seen in traditional reviews. Therefore, our initial two contributions relate to understanding the past and present of the LD field. First, we provide a more thorough and impartial understanding of the evolution of the LD field over time. A second central contribution of this review is its comprehensive and unbiased examination of the current state of the LD field and its structure and communication patterns. Through analyzing the evolution of the field and its current scholarly intellectual structure and by identifying trends and gaps in LD topics, as a third central contribution, we make informed and practical suggestions to guide future $L D$ research. As discussed below, those future research suggestions relate to strengthening existing domains of interest, pursuing crucial underexplored or new topics, and investigating how we can transform the ways scholars research LD. Next, we interpret our findings following those contributions and our original research questions: how we got here, where we are, and where we are headed in the LD field.

\section{How We Got Here}

A central first contribution of this review is its comprehensive and objective examination of the evolution of the LD field. Based on our findings, we make the following central observations about how we got here: (1) the knowledge passed down has evolved around one main narrative, (2) the origins of the LD field lie in practice, and (3) seminal theory on leadership and organizational behavior grounds the LD discourse.

One main narrative of LD. Although we observed a few tangential clusters in the historiography, one main cluster (cluster 1, blue) emerged to dominate the journey of LD knowledge over time. The knowledge passed down in the LD field has evolved through one main paradigm related to the practice of $\mathrm{LD}$ in organizations. The dominant discourse includes key authors such as Avolio, Day, and Lord and their suggested theoretical framing. We also observed the overall dominant influence of The Leadership Quarterly and other top- 
tier publications (e.g., Journal of Applied Psychology, Academy of Management Learning \& Education).

Although this integration and alignment may have helped the LD field advance, it may potentially hamper progress. The LD field has developed into a substantial field of scientific research. We suggest that there should be significant space in the LD conversation for other existing and new frameworks and outlets than a few currently dominant voices. Broader scientific competition may elicit breakthrough perspectives (i.e., theoretical novelty, Glynn \& Raffaelli, 2010) and practically relevant findings. In terms of the outlets where the dominant LD conversation occurs, it appears that other emerging outlets (e.g., Leadership, Human Relations, Human Resource Development Quarterly, Management Learning) could become a stronger source for innovation and integration in future LD research and drive a paradigm shift in the future.

Practice-focused origins of LD. Like the practice-focused origins of the larger field of Organizational Behavior (Porter \& Schneider, 2014), the results of the historiography reveal that the LD field originated with a focus on addressing practical challenges for developing leaders within organizations. Specifically, documents in the dominant cluster 1 (blue) address applied challenges related to developmental assignments, 360-degree feedback, leadership skills and competencies, and executive coaching. These practice-oriented origins are also vibrant in contemporary empirical LD research (e.g., DeRue et al., 2012; DeRue \& Wellman, 2009; Dragoni et al., 2009). Cluster 2 (green), in the bibliographic coupling, was dominated by empirical tests of organizational approaches to LD, such as global work experiences (Dragoni et al., 2014), after-event reviews (DeRue et al., 2012), and mentoring (Lester et al., 2011). Despite these origins and ongoing emphasis on LD practice, scholars continue to discuss the research-practice gap stating, "the relevance of research conducted in the management domain remains in question" (Banks, Pollack, Bochantin, Kirkman, 
Whelpley, \& O'Boyle, 2016, p. 2205). As such, we explore in our discussion of future research how LD scholars can further increase research on practical approaches to LD.

Seminal theory grounds LD discourse. We also observed a strong grounding of LD research in basic theory related to leadership and organizational behavior. Specifically, the results of the co-citation analysis cluster 1 (red) reveal the influence of seminal, primarily conceptual documents focused on leadership (e.g., Bass, 1985; Burns, 1978). These help the field define what good leadership looks like and enable practitioners and scholars to consider how to address those attributes through LD. These studies define for instance different types, styles, and behaviors of leaders (e.g., charismatic leadership, Shamir, House, \& Arthur, 1993), enabling early LD to focus on understanding if and how we can develop those attributes in leaders (e.g., LMX, Graen \& Uhl-Bien, 1995; transformational leadership, Dvir et al., 2002). In explaining this process, researchers heavily relied on traditional organizational behavior theories, including motivation and learning (co-citation cluster 2 green), experiential learning theory (Kolb, 1984), goal-setting theory (Locke \& Latham, 1990), self-efficacy (Bandura, 1977, 1986, 1997), and goal orientation theory (e.g., Dweck, 1986). Prior reviews with a narrowed focus on LD can fail to consider the strong role of these theories in forming the knowledge base underlying the LD conversation, even though they are critical to understanding more broadly how to grow and develop leaders and leadership. From understanding the past, we next turn to the present and future.

\section{Where We Are and Where We Are Headed: Pursuing within frame and frame-breaking}

\section{LD research}

The second contribution of this study resides in its inclusive and objective depiction of the current state of the LD field based on a methodology that is informed by the importance and strength analysis of respective documents. In our findings, documents merge into distinct clusters, or colleges of specific topics amongst a group of scholars (de Solla Price, 1965). In 
short, we have identified the dominant conversants and topics that researchers are listening to in the LD field. We provide the following major observations related to where we are: (1) LD theories are proposed yet not comprehensively investigated, (2) a wide variety of contextual and personal antecedents to LD are independently discussed, (3) we have unmet aspirations for understanding multi-level developmental outcomes and a temporal lens on LD, and (4) unconnected and unrepresented perspectives merit attention. As we discuss these observations, we also provide suggestions for future research in detailing where the LD field is headed. We initially provide potential future investigations within the current paradigm of LD research. Next, we discuss frame-breaking LD research and conclude with suggestions for research strategies to get there. Thus, the third contribution of our paper is the opportunity to draw informed directions for future research, which we summarize in Table 6.

------- INSERT TABLE 6 ABOUT HERE -----

Research direction 1: Pursuing research within the current framing of LD. Our studies show a gap between theoretical suggestions and aspirations in the LD field and the reality of empirical work. Hence, the first three suggestions for research themes point to fulfilling some long-standing aspirations of the field.

LD theories are proposed, yet not comprehensively investigated. Our first observation for the current state of the LD field concerns the establishment and empirical examination of extant LD theory. We observed a couple of major categories of LD theory that are dominant yet not fully investigated: identity development and authentic leadership development.

Starting with leader identity development theory, The Leadership Quarterly publication by Lord and Hall (2005) played a key role in all three bibliometric analyses. This paper was the second and third highest weighted document in the historiography and co-citation analysis, respectively, and formed its lynchpin cluster in the bibliographic coupling analysis. Beyond this highly influential paper, leader identity was a dominant theme in cluster 3 (blue) 
of the co-citation analysis including elaboration on Lord's work (e.g., DeRue \& Ashford, 2010, claiming and granting) as well as theoretical work by social psychologists on leader identity development (e.g., Hogg, 2001; van Knippenberg et al., 2004).

The importance of Lord and Hall (2005) and related work on leader identity development has several explanations. First, discussing LD outcomes only in terms of competencies and the behaviors associated with specific leadership styles is problematic. Not only are competency models controversial (see Hollenbeck, McCall, \& Silzer, 2006), but new leadership styles frequently emerge, even though meta-analytic research indicates that they may lack incremental validity (e.g., authentic leadership; Banks et al., 2016; Hoch et al., 2018). Additionally, LD requires a long-term commitment, and the development of a leader identity can be a factor in sustaining motivation and interest in LD over time. Finally, structural changes at the identity level support the development of more complex leadership skills (Day \& Dragoni, 2015).

Lord and Hall's (2005) work on leader identity is clearly influential, and some authors have both theoretically and empirically developed their theoretical claims (e.g., Day \& Harrison, 2007; Day, Harrison, \& Halpin, 2009; Epitropaki et al. 2017), including some empirical testing (e.g., Day \& Sin, 2011). More recent research continues the theoretical work for instance by examining leader identity development beyond the workplace and across multiple domains (Hammond, Clapp-Smith, \& Palanski, 2017), trajectories of leader identity (Miscenko, Guenter, \& Day, 2017; Middleton, Walker, \& Reichard, 2019), and the role of coaching in supporting new leaders to integrate multiple identities within their leader identity (Yip et al., 2019). Given the dominant role of leader identity development in the existing LD narrative, further rigorous empirical work is needed to assess existing and emerging theories.

One limitation to research on leader identity is the self-referential nature of the construct and associated measures. In examining empirical work on the topic, the most commonly 
employed measure of leader identity seems to be based on self-report agreement responses to items such as 'I am a leader' (Hiller, 2005). Such measures rely on the respondent's implicit leadership theory of what it means to be a leader (Schyns \& Meindl, 2005). An alternative approach to assessing leader identity is to, first, capture the respondent's implicit leadership theory by asking them to indicate the traits and/or behaviors of a leader and, second, ask the respondent to rate themselves on those traits and/or behaviors. This approach may more accurately capture the respondent's leader identity in relation to how they define what it means to be a leader.

However, an overemphasis on leader identity development may limit future insights. First, with leader identity development mainly situated in individual-level research, it further drives the bias of the LD field towards micro research. Hence theoretical and empirical work in this area should also focus on higher levels of analysis (e.g., DeRue, 2011), for instance, the role of leadership identity processes involving multiple organizational members. Second, leader identity development research is cognitively-oriented by emphasizing how one's mental models or cognitive schemas change over time. As we later discuss, future LD research would benefit from considering more affective factors in the LD process.

A second, untested, and dominant theoretical category in the LD field is authentic leadership development. Results of both the historiography (cluster 1 blue) and co-citation analysis (cluster 1 red) indicate a dominant role of primarily theoretical documents on authentic leadership development. Arguably, the 2005 special issue in The Leadership Quarterly on authentic leadership development marks a concentrated effort to balance the practice-oriented LD roots with a comprehensive theory dedicated to the development of leaders, specifically. Thus, rather than discussing how leaders can embody a particular leadership style (e.g., transformational), the dominant and origin work on authentic leadership 
development theorized a multi-level process specifying how leadership develops over time (Gardner et al., 2005).

Despite this original theoretical emphasis on development, most-cited empirical work on authentic leadership reverted to examining it as a style or set of behaviors (e.g., selfawareness, balanced processing, relational transparency, and internalized moral perspective; Walumbwa et al., 2008) and tested its effectiveness while neglecting the theory's emphasis on development. The developmental processes underlying the original, dominant theory papers on the topic (e.g., Gardner et al., 2005), however, go well beyond authentic leadership as a set of behaviors. They emphasize the role of personal history, organizational context, work environment, and authentic follower development (Avolio \& Reichard, 2008), but scholars have largely empirically ignored those aspects. Likely due to its complex (i.e., multi-level, longitudinal) nature, empirically testing the theory of authentic leadership developmental has been challenging for LD researchers; however, this is true for the LD field overall. Future research can focus on rigorous, multi-level, longitudinal, empirical research testing the original, dominant theory papers on the development of authentic leadership.

Finally, our results show that the dominant documents in our study for authentic leadership development research have essentially one underlying core theoretical framework (e.g., Gardner, et al., 2005; Walumbwa et al., 2008). This focus may pose the risk that scholars overlook limitations in this theoretical underpinning, thus hampering scientific progress. In addition to further empirical work, future research can intensify attempts to challenge and extend the theoretical understanding of both authenticity (e.g., Ford \& Harding, 2011) and developmental aspects (Algera \& Lips-Wiersma, 2012; Berkovich, 2014) of this theory. In short, we suggest a return to empirically and theoretically examining the development component of authentic leadership development. Next, we turn to our second major observation and associated suggestions for future research. 
A wide variety of contextual and personal antecedents to LD are independently

discussed. Overall, LD authors emphasized a broad range of contextual antecedents, including interventions like training and education, experience-based learning and developmental assignments, personal history, trigger events, and adversity, feedback, coaching, and mentoring. Personal antecedents were even more frequently discussed, such as learning attitudes and processes, motivational processes (e.g., feedback-seeking, motivation to lead, learning orientation), and self-related processes (e.g., self-awareness, identity, implicit theories). Despite the emphasis on these interventions and antecedents in the LD conversation, each is often researched in isolation. Future research could differentiate LD interventions and antecedents in more detail and investigate their relative impact over time (Day et al., 2014) or examine the effect of their ordering and sequencing on LD outcomes. The LD field can then go beyond discrete learning events and focus on process-based development in organizations (Gagnon \& Collinson, 2014).

We have unmet aspirations for understanding multi-level developmental outcomes and for a temporal lens on $L D$. The distinction between individual-level leader development and collective-level leadership development by Day (2000) has transformed thinking in the field of LD, as reflected through its dominant status in our review. Since then, the conversation in the LD field is replete with aspirations for multi-level research. In the bibliographic coupling analysis, ideal for foreshadowing future trends, the dominant document by Day and Dragoni (2015) continued the emphasis on multi-level LD outcomes and expanded this perspective to incorporate the dimension of time. Clearly, the past and current LD conversations emphasize the importance of examining multi-level developmental outcomes over time.

However, our coding uncovered a disconnect between these dominant aspirations and the reality of empirical research. For developmental outcomes, empirical research rarely investigated collective outcomes as compared to individual outcomes. The overemphasis on 
the leader development versus leadership development duality may prevent a more nuanced, multi-level approach to LD. Day and Dragoni's (2015) multi-level, temporal outcome review further reinforces this duality as they only specify outcomes at the individual and team level, neglecting the organizational and societal levels. Given the dominance of the aforementioned reviews, the extant lack of empirical emphasis on collective outcomes and on the role of time in LD uncovers critical areas of future research.

Correspondingly, research could pursue studies at multiple levels, for instance within or across intra-individual (e.g., leader and follower identities and/or leadership and followership behavior), dyadic and/or team (e.g., developing leader-follower processes, collective/team leadership capability), and organization-wide leadership capability levels (e.g., developing leadership climate, Chen, \& Bliese, 2002; Menges, Walter, Vogel, \& Bruch, 2011). To do so, we suggest utilizing a more nuanced differentiation for multi-level research into micro multi-level, meso multi-level, and macro multi-level research (see Batistič et al., 2017). We do not expect researchers to work across all levels of analysis, but instead, future research can more intentionally extend investigations across specific levels. This approach then requires integrating theory and literature from different levels such as self-development (Boyce, Zaccaro, \& Wisecarver, 2010; Reichard \& Johnson, 2011) with team leadership, distributed leadership (Bolden 2011), leadership in and of networks, or organizational development (Day \& Dragoni, 2015). For instance, although collective or distributed leadership has gained prominence (e.g., Denis, Langley, \& Sergi, 2012) and found entry in the intellectual structure of LD (e.g., Bolden 2011), this is mostly theoretical work and neglects how to develop distributed leadership capabilities.

Results show a similar gap between aspiring for a temporal lens to LD and making the timing of and time for LD a substantial and regular element of theory and empirical studies. Even at the individual level of analysis as the most researched area, we have a limited 
theoretical understanding of the role of time in the development of desired outcomes (e.g., Day \& Dragoni, 2015, proximal and distal outcomes). Despite a few initial studies on developmental trajectories of leader identity (e.g., Miscenko, Guenter, \& Day, 2017; Middleton, Walker, \& Reichard, 2019), we lack a theoretical and empirical understanding of how much time an individual requires to develop other common individual-level developmental outcomes, (e.g., knowledge, skills, abilities, behaviors, and competencies or leader self-efficacy, self-awareness). For example, will the skill of active listening develop within the same timeframe as cognitive complexity? How long does it take to develop swift trust versus psychological safety as indicators of leadership development? Given the topics longitudinal nature, every future empirical study on LD should incorporate a temporal focus.

Research direction 2: Striving for frame-breaking LD research. Our results across the three bibliometric methods allow us to identify dominant voices and topics in the LD narrative in need of further study, but we also identify three promising perspectives that are unrepresented or unconnected and have the potential for theoretical novelty and breakthrough thinking (Glynn \& Raffaelli, 2010). Three perspectives ripe for frame-breaking LD research include the following: (1) fostering disconnected LD research on unrepresented, demographically diverse leaders, (2) researching detrimental aspects of LD, and (3) researching the role of affect in LD.

Fostering disconnected $L D$ research on unrepresented, demographically diverse leaders. First, we observed that documents on women's LD were disconnected from the primary narrative and only a very small percentage of documents included gender as a focus (e.g., Eagly \& Karau, 2002; Ely et al., 2011). Moreover, we noticed that no study in our sample of influential papers discussed LD for other demographic groups not typically represented in leadership roles. Still, those demographic groups are increasing (or increasingly visible) in the population overall. Whereas diversity and inclusion have become a burgeoning 
topic in mainstream organizational behavior research (Roberson, 2019), we observe a lack of theory and research on women, minority, and LGBTQ+ leadership development in the influential LD conversation. Perhaps, the lack of emphasis on LD for diverse groups is an artifact of the dominance of U.S.-based, Caucasian, male conversants in the LD field. Either way, the field of LD is not reflective of the modern workforce, even though most leaders today in the western hemisphere are still Caucasian men. By not focusing significant research on LD of diverse groups, we perpetuate biased systems that prevent the emergence of diverse leaders in the first place. By expanding research toward the understanding of the LD of diverse group members, which may vary in different global regions, we break the frame of existing perspectives that leadership is only for Caucasian men.

Top co-citation documents by Eagly and Karau (2002) and Ely et al. (2011) delineate the unique challenges and barriers faced by women as they develop into leaders, such as role (in)congruity between gender and leader roles, gender bias and gendered career paths in organizations, and lack of role models and sponsors in women's networks. Minority and LGBTQ+ leaders likely face similar and unique challenges and barriers. Future research could begin by theory building and employing qualitative research methods to investigate unique or similar developmental experiences, barriers, and needs of minority and LGBTQ+ organizational members when developing as leaders or collective leadership capabilities.

Researching detrimental aspects of $L D$. Second, we found neglect of research focused on the detrimental aspects of LD. A few themes that did occur were negative effects of developmental challenge, nuances related to feedback interventions, non-linear growth trajectories, and challenges related to diversity. Overall, however, authors tend to choose themes oriented toward positive processes and results of LD and to overlook the need to investigate that LD can be harmful to individuals and organizations. Without thoroughly 
understanding when and how LD becomes detrimental, LD practice cannot be supported in identifying, avoiding, and overcoming harmful developmental processes and outcomes.

As a response, LD research can pursue three different tangible avenues. First, future research can further focus on potential negative experiences or consequences of LD processes, such as emotional exhaustion from experiential learning (e.g., Courtright, Colbert, \& Choi, 2014) or fear of applying learned behaviors, gendered differences in outcomes of LD processes (Ely et al., 2011; Fitzsimmons, Callan, \& Paulsen, 2014), or status and identity separation between those with and without opportunities for leadership learning.

Second, in combination with our call for an intensified temporal lens on LD future studies, researchers can investigate the potential decreasing utility or inflection points of LD processes under the umbrella of "too much of a good thing" literature (Le, Oh, Robbins, Ilies, Holland, \& Westrick, 2011; Pierce \& Aguinis, 2013). As a theoretical starting point, future research can adapt McClean, Barnes, Courtright, and Johnson's (2019) framework of different types of temporal dynamics of leader behavior such as shifts, growth, or decay to the LD field. Studies can theorize and investigate how and why the development of leader identity and behavior, or collective leadership capability may show trajectories of growth, but also decline or plateau (periods of non-development). Research can also explore whether, for instance, developing leader efficacy can reach saturation or inflection points. Can managers develop over-confidence in their ability to lead limiting participative or shared leadership and, ultimately, harming the quality of leader-follower relationships? For LD interventions, longitudinal studies can investigate diminishing returns from sequential interventions of similar or different natures (e.g., experience-based learning, stretch assignments).

Finally, research can investigate trade-offs between beneficial and detrimental outcomes. For instance, scholars could examine if collective LD processes (e.g., the successful development of leadership capability in intact management teams or cohort of high 
potentials) facilitate unwanted separation between teams and cohorts in an organization. That means research can investigate if tensions, cynicism, or alienation emerge between those teams or individual managers selected for LD initiatives and those who were not. Overall, investigating the positive and negative spectrum of LD offers a more realistic and scientifically sound understanding of LD and its sustained effects and can help avoid negative outcomes of LD of what is generally considered a positive process.

Researching the role of affect in $L D$. Third, we observe that the LD field tends to be biased towards cognitive theorizing and predominantly lacks emotion and affect-related theory and processes. Exceptions from dominant documents research emotional awareness as a target for LD (Day 2000; Gardner et al., 2005) or emotional regulation as a mechanism to develop leadership skill (Lord \& Hall, 2005). Emerging research focuses on emotional exhaustion from experience-based learning (Courtright et al., 2014) or leader emergence as a negative affective experience (Edwards et al., 2013). Although research on LD outcomes at times considers overall satisfaction and commitment, it generally overlooks affective experiences in $\mathrm{LD}$ processes. Therefore, theorizing and scientific progress in the LD field may fundamentally benefit from an affective turn as did the domains of leadership or organizational behavior since they more systematically considered affect from the 1990s onwards (Barsade, Brief, \& Spataro, 2003; Gooty, Connelly, Griffith, \& Gupta, 2010).

Future research can strengthen tangible research themes about negative or positive affective experiences. First, one of the dominant assumptions in the LD field is that leadership learning stems from experiencing hardships and adversity in work assignments (McCall, Lombardo, \& Morrison, 1988). For example, the receipt of 360-degree feedback may result in a negative emotional reaction that causes a temporary dip in leader identity (Middleton et al., 2019). New light can be shed on the LD process by understanding when and why experiential 
learning from adversity results in unpleasant feelings (Dong et al., 2014) or how stress and anxiety affect development and performance expectations (DeRue \& Wellman, 2009).

Second, future empirical studies can examine the role of positive affective experiences for LD. This perspective builds on early-stage conceptual work on how positive job experiences (DeRue \& Workman, 2012; Spreitzer, 2006) or positive work and learning environments stimulate individual or collective leadership capabilities (Vogel, 2017). Broaden and build theory posits positive emotions stimulate organizational members' approach-action tendency and broaden their thought-action repertoires (Fredrickson, 1998), which addresses crucial LD components. Hence, research can explore questions such as: Do individuals' or cohorts' feelings of excitement and joy during learning periods help or hinder LD outcomes? In terms of LD initiatives, do positive or negative affective experiences have spill-over effects on social spheres beyond work such as partners and family? Do those spillover effects shape spirals of positive or negative feelings towards the LD process, potentially facilitating or interfering with developmental processes and outcomes?

\section{Research direction 3: How We Can Get There - Transforming LD Research}

So far, we identified future research directions within the current framing of LD research and as frame-breaking LD studies to make the field more scientifically insightful and meaningful for practice. In this section, we move beyond those mainly theme-based suggestions by detailing the following explicit research strategies and activities that researchers can take to transform the ecosystem of $L D$ research and practice: 1) advancing research-practice partnerships and 2) understanding implicit leadership development theory.

Advancing Research-Practice Partnerships. As previously noted, top documents in the historiography study allow us to trace the origin of research in the LD field back to addressing LD challenges and practices faced by leaders and organizations. We also found that top documents in the co-citation analysis emphasize longitudinal, field experiments that 
investigate developing leadership within organizations. As noted earlier, future research should include alternative perspectives to LD, such as constructivist, critical, and pragmatic orientations (e.g., Mabey, 2013) that also require in-depth interactions in and with organizations for qualitative methodologies, ethnography, or action research.

Following these origins and trends, we assert that the future of LD research lies in indepth research-practice partnerships, such as labs or communities of co-creation, that build overlapping purposes, overcome tensions between academic and practice stakeholders (Bartunek \& Rynes, 2014), and "foster collaboration through capitalizing on differing perspectives" (Banks et al., 2016, p. 2230). Such a collaborative model can co-create LD research that connects developmental opportunities and pressures in organizations with scientific rigor, curiosity, and expertise to ultimately support the research and practice of LD. Strong research-practice partnerships also allow the pursuit of more complex, relevant, or radical LD questions such as the following: How can LD theory and practice create purposerich LD practices that address society's grand challenges (Banks et al., 2016)? For example, how can the LD field explicitly aim to contribute to the United Nations sustainable development goals (e.g., climate change) directly with its impact in organizations, but also with positive spillover effects where organizational members employ developed leadership capacity in other social spheres such as families or community work (Hammond et al., 2017)? How do tangible contexts, such as the physical, brick and mortar environment, help or hinder LD processes and outcomes at work? These are just a couple of examples of questions that may benefit both researchers and practitioners to answer. The overall practical benefit of researcher-practitioner partnerships is the enablement of effective and meaningful organizational research that matches the LD field's aspirations for longitudinal and multilevel research on LD antecedents and outcomes using experimental, quasi-experimental, or indepth qualitative methods. 
In addition to providing organizations, decision-makers, and learners with rapid and longer-term evidence-based practice, strategic research-practice partnerships simultaneously allow contemporary insights that advance the LD field. Those types of partnerships can themselves be the focus of LD research because they present a novel or rediscovered type of practice-academic ecosystem. Studies can investigate their functioning and effectiveness toward sustained impact on leadership capability in practice and on the scientific progress of the LD field. One tangible step to initiate those partnerships can be to collaborate in local alliances in the area of business school/university instead of working with global organizations, which combines knowledge creation with a potential community effect. In doing so, LD researchers can identify and investigate outstanding local LD practice that fits or enriches their LD research agenda. On the other side, organizational practitioners need to understand the importance of knowledge creation and, thus, invest in and prioritize evidencebased solutions to their LD challenges instead of hopping on a bandwagon related to the latest popular trade books or fleeting concepts. Neither of these perspectives will change quickly, so we suggest a starting point is to conduct such research investigating what we suggest in the following as implicit leadership development theory.

Exploring implicit leadership development theory. Banks et al. (2016) recommend that "academics need to be better at speaking the language of management in the real world" (p. 2228). Likewise, dominant documents from our analysis suggest that assumptions about LD held in practice can limit the application of research insights and recommendations (Avolio \& Chan, 2008). To understand those potential disconnects between science and practice better, we suggest investigating the beliefs, identities, or assumptions about essential elements of LD processes that salient stakeholders of the LD ecosystem hold (e.g., learner, LD experts, decision-makers, scholars, LD designers, and members of wider society). We suggest framing this as implicit leadership development theory (ILDT). 
Leadership scholars define implicit leadership theories as cognitive structures that people hold about the attributes and abilities of leaders (Epitropaki, Sy, Martin, Tram-Quon, \& Topakas, 2013; Lord, Foti, \& De Vader, 1984). We propose that ILDTs can describe the cognitive structures of stakeholders regarding LD. Stakeholders with potentially differing ILDTs include LD scholars, LD practitioners, the focal learner, and others.

The three following examples of facets of ILDTs can illustrate how an improved understanding of similarities and differences in ILDTs may help or hinder research-practice partnerships, devising LD initiatives and, ultimately, LD outcomes. First, ILDTs include implicit beliefs about the malleability of leadership, particularly whether the ability to engage successfully in leadership is a born versus made attribute (Avolio, 2005). Second, implicit beliefs can differ along where and how leadership develops, such as within a formal program versus holistically over the lifespan, day-to-day, or both within and outside of organizations (Hammond, Clapp-Smith, \& Palanski, 2017). Third, stakeholders in LD might vary in their implicit beliefs of what the emphasis of LD initiatives should be. Should LD target specific competencies or whole person attributes such as leader identity? Should it address followership (e.g., follower schemas and behaviors; Carsten, Uhl-Bien, West, Patera, \& McGregor, 2010) or shared leadership capabilities (e.g., shared sense-making)?

An understanding of such implicit beliefs among LD stakeholders can advance LD by narrowing the research-practice gap, facilitating a common language in the LD eco-system, and capitalizing on multiple perspectives. Surfacing assumptions about LD and building common ILDTs can result in better designs of LD initiatives, improved translation and transfer of insights from academic research to practice (cf., Schyns, Kiefer, Kerschreiter \& Tymon, 2011), and substantially extended understanding and impact of the LD field.

\section{Limitations}


As with all research, the present study is not immune to limitations. First, although we believe that the keywords chosen have face validity, the selection of specific keywords to describe the LD field might have some influence on our results (Batistič \& van der Laken, 2019). For example, we excluded "leader training" or "leadership training" and included "management training" in our search terms. The latter likely captures topics such as meeting management, hiring practices, basic communication skills, which some may not consider LD. However, the advantage of the bibliometric methodology is that it uses citation patterns to determine if those themes are, in fact, dominant. Our results did not highlight such topics as important to the LD narrative.

Second, selecting a citation threshold to include documents enables the feasibility of this study, but may have introduced bias into an otherwise relatively objective bibliometric approach, especially for smaller clusters (Batistič et al., 2017). To minimize this impact, we followed the proposed guidelines (Batistič \& van der Laken, 2019; Garfield et al., 2003; van Eck \& Waltman, 2014a) wherein we compared different thresholds to test the robustness of our analyses, and we did not find substantial differences. Despite the use of a citation threshold, our review was both comprehensive and objective contrasted with prior reviews, with a large number of important documents determined through citation counts.

Lastly, bibliometric approaches do not capture why authors cite other works (Zupic \& Čater, 2015). For example, the citing behavior of authors can be a result of self-legitimization strategies, homogenizing, micropolitics, issues with the peer review process, or criticism about specific work (Bornmann \& Daniel, 2008; Tsang \& Frey, 2007; Tsui, 2013; Zupic \& Čater, 2015). Generally, such issues are important, but some cannot be captured or addressed by the bibliometric methods (e.g., peer review issues, self-legitimization strategies such as self-citation, or citations from friendly colleagues or graduate students). Bibliometric studies and simulations argue that self-citation is an organic part of the citation process and as such 
should not be removed from important inferential statistics (e.g., Wolfgang et al., 2004; Glanzel et al., 2006). We also conducted additional analyses that ruled out that self-citation might lead to problematic results in this study. ${ }^{3}$ Finally, avoiding the homogenization of good research in only top journals (Tsui, 2013) is a defining element of our methodology. We included a comprehensive sample of 2,390 primary (citing) and 78,178 secondary (cited) documents unbeknown to type of document and outlet in our analysis, which should alleviate such concerns and goes beyond what traditional reviews or meta-analysis are capable.

\section{Conclusion}

The purpose of this paper was to provide a comprehensive, objective, and integrative review of the LD field. We utilized three bibliometric methods and identified and interpreted how the knowledge domain of LD has evolved and its current intellectual debates, structure, and trends. We content analyzed top documents to detail the LD discourse further. Based on our findings, we derived a distinct set of theoretically and practically relevant future research directions that can substantially advance the science and practice of LD. Depending on the area of expertise, but also the ambition of current and future researchers, we provide the following three substantial research directions they can engage: (1) research themes within the current research framing that are overdue for investigation, (2) research themes that are about frame-breaking research to address unconnected and unrepresented perspectives, and (3) research themes and strategies that investigate at the systems-level how to transform the way we pursue research and practice. We hope that findings inspired by our suggestions for future research can significantly add to the growing and unique body of work with in the field of LD and support success in the practice of LD.

\footnotetext{
${ }^{3}$ Contact the corresponding author for additional details of this analysis.
} 


\section{References}

Algera, P. M., \& Lips-Wiersma, M. (2012). Radical Authentic Leadership: Co-creating the conditions under which all members of the organization can be authentic. Leadership Quarterly, 23(1), 118-131.

Atwater, L., \& Waldman, D. (1998). 360 degree feedback and leadership development. Leadership Quarterly, 9(4), 423.

Avolio, B. J. (2005). Leadership development in balance. Mahwah, NJ: Lawrence Erlbaum Assosiates, Inc..

Avolio, B. J. (2007). Promoting more integrative strategies for leadership theory-building. American Psychologist, 62(1), 25-33.

Avolio, B. J., Avey, J. B., \& Quisenberry, D. (2010). Estimating return on leadership development investment. The Leadership Quarterly, 21(4), 633-644.

Avolio B.J. \& Chan A. (2008). The dawning of a new era for genuine leadership development. In International Review of Industrial and Organizational Psychology, ed. G Hodgkinson, K Ford, (197-238). New York: Wiley.

Avolio, B. J., \& Gardner, W. L. (2005). Authentic leadership development: Getting to the root of positive forms of leadership. The Leadership Quarterly, 16(3), 315-338.

Avolio, B. J., Gardner, W. L., Walumbwa, F. O., Luthans, F., \& May, D. R. (2004). Unlocking the mask: A look at the process by which authentic leaders impact follower attitudes and behaviors. Leadership Quarterly, 15(6), 801-823.

Avolio, B. J., Reichard, R. J., Hannah, S. T., Walumbwa, F. O., \& Chan, A. (2009). A metaanalytic review of leadership impact research: Experimental and quasi-experimental studies. The Leadership Quarterly, 20(5), 764-784. 
Avolio, B.J. \& Reichard, R.J. (2008). The rise of authentic followership. In R.E. Riggio, I. Chaleff, \& J. Lipman-Blumen (Eds.) The art of followership (pp. 325-337). San Francisco, CA: Jossey-Bass.

Baldwin, T. T., \& Ford, J. K. (1988). Transfer of training: A review and directions for future research. Personnel Psychology, 41(1), 63-105.

Bandura, A. (1977). Self-efficacy: Toward a unifying theory of behavioral change. Psychological Review, 84(2), 191-215.

Bandura, A., \& National Inst of Mental Health. (1986). Prentice-Hall series in social learning theory. Social foundations of thought and action: A social cognitive theory. Englewood Cliffs, NJ, US: Prentice-Hall, Inc.

Bandura, A. (1997). Self-efficacy: The exercise of control. New York, NY, US: W H Freeman/Times Books/ Henry Holt \& Co.

Banks, G.C., Pollack, J.M., Bochantin, J.E, Kirkman, B.L., Whelpley, C.E., \& O’Boyle, E.H. (2016). Management's science-practice gap: A grand challenge for all stakeholders. Academy of Management Journal, 59(6), 2205-2231.

Barsade, S., Brief, A., \& Spataro, S. (2003). The affective revolution in organizational behavior: The emergence of a paradigm. In J. Greenberg (Ed.), Organizational Behavior: The State of the Science (pp. 3-52). London: Lawrence Erlbaum Associates.

Bartunek, J. M. \& Rynes, S. L. (2014). Academics and practitioners are alike and unlike: the paradoxes of academic-practitioner relationships. Journal of Management, 40(5), 1181-1201.

Bass, B. M. (1985). Leadership and performance beyond expectations. New York: Free Press. 
Batistič, S., Černe, M., \& Vogel, B. (2017). Just how multi-level is leadership research? A document co-citation analysis 1980-2013 on leadership constructs and outcomes. The Leadership Quarterly, 28(1), 86-103.

Batistič, S., \& Kaše, R. (2015). The organizational socialization field fragmentation: a bibliometric review. Scientometrics, 104(1), 121-146.

Batistič, S., \& van der Laken, P. (2019). History, Evolution and Future of Big Data and Analytics: A Bibliometric Analysis of Its Relationship to Performance in Organizations. British Journal of Management, 30(2), 229-251.

Berkovich, I. (2014). Between person and person: Dialogical pedagogy in authentic leadership development. Academy of Management Leaning \& Education, 13(2), 245264.

Bolden, R. (2011). Distributed leadership in organizations: A review of theory and research. Information Journal of Management Reviews, 13(3), 251-269.

Bornmann, L., \& Daniel, H.-D. (2008). What do citation counts measure? A review of studies on citing behavior. Journal of Documentation, 64(1), 45-80.

Boyatzis, R. E., Smith M. L., \& Blaize, N. (2006). Developing sustainable leaders through coaching and compassion. Academy of Management Learning \& Education, 5(1), 824.

Boyce, L. A., Zaccaro, S. J., \& Wisecarver, M. Z. (2010). Propensity for self-development of leadership attributes: Understanding, predicting, and supporting performance of leader self-development. The Leadership Quarterly, 21(1), 159-178.

Burke, M. J., \& Day, R. R. (1986). A cumulative study of the effectiveness of managerial training. Journal of Applied Psychology, 71(2), 232-245.

Burns, J. M. G. (1978). Leadership. New York: Harper \& Row. 
Carroll, B. \& Simpson, B. (2012). Capturing sociality in the movement between frames: An illustration from leadership development. Human Relations, 65(10), 1283-1309.

Carsten, M. K., Uhl-Bien, M., West, B. J., Patera, J. L., \& McGregor, R. (2010) Exploring social constructions of followership: a qualitative study. The Leadership Quarterly, 21 (3), 543-62

Chen, G., \& Bliese, P. D. (2002). The role of different levels of leadership in predicting self and collective efficacy: Evidence for discontinuity. Journal of Applied Psychology, 87, $549-556$.

Collins, D. B., \& Holton, E. F., III. (2004). The Effectiveness of Managerial Leadership Development Programs: A Meta-Analysis of Studies from 1982 to 2001. Human Resource Development Quarterly, 15(2), 217-248.

Cooper, C. D., Scandura, T. A., \& Schriesheim, C. A. (2005). Looking forward but learning from our past: Potential challenges to developing authentic leadership theory and authentic leaders. The Leadership Quarterly, 16(3), 475-493.

Courtright, S. H., Colbert, A. E., \& Choi, D. (2014). Fired up or burned out? How developmental challenge differentially impacts leader behavior. Journal of Applied Psychology, 99(4), 681-696.

Day, D. V. (2000). Leadership development: A review in context. The Leadership Quarterly, 11(4), 581-613.

Day, D. V., \& Dragoni, L. (2015). Leadership development: An outcome-oriented review based on time and levels of analyses. Annual Review of Organizational Psychology and Organizational Behavior, 2, 133-156.

Day, D. V., Fleenor, J. W., Atwater, L. E., Sturm, R. E., \& McKee, R. A. (2014). Advances in leader and leadership development: A review of 25 years of research and theory. The Leadership Quarterly, 25(1), 63-82. 
Day, D. V., \& Harrison, M. M. (2007). A multilevel, identity-based approach to leadership development. Human Resource Management Review, 17(4), 360-373.

Day, D. V., Harrison, M. M., \& Halpin, S. M. (2009). An integrative approach to leader development: Connecting adult development, identity and expertise. New York, NY, US: Routledge/Taylor \& Francis Group.

Day, D. V. (2011). Integrative perspectives on longitudinal investigations of leader development: From childhood through adulthood. The Leadership Quarterly, 22(3), $561-571$.

Day, D. V., \& Sin, H.-P. (2011). Longitudinal tests of an integrative model of leader development: Charting and understanding developmental trajectories. The Leadership Quarterly, 22(3), 545-560.

Denis, J.-L., Langley, A., \& Sergi, V. (2012). Leadership in the plural. The Academy of Management Annals, 6(1), 211-283.

DeRue, D. S. (2011). Adaptive leadership theory: Leading and following as a complex adaptive process. Research in Organizational Behavior, 31, 125-150.

DeRue, D. S., \& Ashford, S. J. (2010). Who will lead and who will follow? A social process of leadership identity construction in organizations. The Academy of Management Review, 35(4), 627-647.

DeRue, D. S., \& Wellman, N. (2009). Developing leaders via experience: The role of developmental challenge, learning orientation, and feedback availability. Journal of Applied Psychology, 94(4), 859-875.

DeRue, D. S., Nahrgang, J. D., Hollenbeck, J. R., \& Workman, K. (2012). A quasiexperimental study of after-event reviews and leadership development. Journal of Applied Psychology, 97(5), 997-1015. 
DeRue, D. S., \& Workman, K. M. (2012). Toward a positive and dynamic theory of leadership development. In G. M. Spreitzer \& K. S. Cameron (Eds.), The Oxford handbook of positive organizational scholarship. New York, NY: Oxford University Press.

de Solla Price, D. J. (1965). Networks of Scientific Papers Science, 149(3683), 510-515.

Dong, Y., Seo, M.-G., \& Bartol, K. M. (2014). No pain, no gain: An affect-based model of developmental job experience and the buffering effects of emotional intelligence. Academy of Management Journal, 57(4), 1056-1077.

Dragoni, L., Oh, I.-S., Tesluk, P. E., Moore, O. A., VanKatwyk, P., \& Hazucha, J. (2014). Developing leaders' strategic thinking through global work experience: The moderating role of cultural distance. Journal of Applied Psychology, 99(5), 867-882.

Dragoni, L., Tesluk, P. E., Russell, J. E. A., \& Oh, I.-S. (2009). Understanding managerial development: Integrating developmental assignments, learning orientation, and access to developmental opportunities in predicting managerial competencies. Academy of Management Journal, 52(4), 731-743.

Dvir, T., Eden, D., Avolio, B. J., \& Shamir, B. (2002). Impact of transformational leadership on follower development and performance: A field experiment. Academy of Management Journal, 45(4), 735-744.

Dweck, C. S. (1986). Motivational processes affecting learning. American Psychologist, 41(10), 1040-1048.

Dweck, C. S., \& Leggett, E. L. (1988). A social-cognitive approach to motivation and personality. Psychological Review, 95(2), 256-273.

Eagly, A. H., \& Karau, S. J. (2002). Role congruity theory of prejudice toward female leaders. Psychological Review, 109(3), 573-598. 
Edwards, G., Elliott, C., Iszatt-White, M., \& Schedlitzki, D. (2013). Critical and alternative approaches to leadership learning and development. Management Learning, 44(1), 310.

Ely, K., Boyce, L. A., Nelson, J. K., Zaccaro, S. J., Hernez-Broome, G., \& Whyman, W. (2010). Evaluating leadership coaching: A review and integrated framework. The Leadership Quarterly, 21(4), 585-599.

Ely, R. J., Ibarra, H., \& Kolb, D. M. (2011). Taking gender into account: Theory and design for women's leadership development programs. Academy of Management Learning \& Education, 10(3), 474-493.

Epitropaki, O., Kark, R., Mainemelis, C., \& Lord, R. G. (2017). Leadership and followership identity processes: A multilevel review. The Leadership Quarterly, 28(1), 104-129.

Epitropaki, O., Sy, T., Martin, R., Tram-Quon, S., \& Topakas, A. (2013). Implicit Leadership and Followership Theories "in the wild": Taking stock of information-processing approaches to leadership and followership in organizational settings. The Leadership Quarterly, 24(6), 858-881.

Feldman, D. C., \& Lankau, M. J. (2005). Executive Coaching: A Review and Agenda for Future Research. Journal of Management, 31(6), 829-848.

Fiedler, F. (1967). A theory of leadership effectiveness. New York: McGraw-Hill.

Fitzsimmons, T. W., Callan, V. J., \& Paulsen, N. (2014). Gender disparity in the C-suite: Do male and female CEOs differ in how they reached the top? The Leadership Quarterly, 25(2), 245-266.

Ford, J., \& Harding, N. (2011). The impossibility of the "true self" of authentic leadership. Leadership, 7(4), 463-479.

Fredrickson, B. L. (1998). What good are positive emotions? Review of General Psychology, 2(3), 300-319. 
Fulmer, R. M. (1997). The evolving paradigm of leadership development. Organizational Dynamics, 25(4), 59-72.

Gagnon, S., \& Collinson, D. (2014). Rethinking global leadership development programmes: The interrelated significance of power, context and identity. Organization Studies, $35(5), 645-670$.

Gagnon, S., Vough, H. C., \& Nickerson, R. (2012). Learning to lead, unscripted: Developing affiliative leadership through improvisational theatre. Human Resource Development Review, 11(3), 299-325.

Galli, E. B. \& Muller-Stewens, G. (2012). How to build social capital with leadership development: Lessons from an explorative case study of a multibusiness firm. The Leadership Quarterly, 23(1),176-201.

Gardner, W. L., Avolio, B. J., Luthans, F., May, D. R., \& Walumbwa, F. (2005). "Can you see the real me?" A self-based model of authentic leader and follower development. The Leadership Quarterly, 16(3), 343-372.

Garfield, E. (1979). Is citation analysis a legitimate evaluation tool? Scientometrics, 1(4), 359375.

Garfield, E. (2004). Historiographic Mapping of Knowledge Domains Literature. Journal of Information Science, 30(2), 119-145.

Garfield, E., Pudovkin, A. I., \& Istomin, V. S. (2003). Why do we need algorithmic historiography? Journal of the American Society for Information Science and Technology, 54(5), 400-412.

George, B., Sims, P., McClean, A., \& Mayer, D. (2007). Discovering your authentic leadership. Harvard Business Review, 85(2), 1-9.

Gooty, J., Connelly, S., Griffith, J., \& Gupta, A. (2010). Leadership, affect and emotions: A state of the science review. The Leadership Quarterly, 21(6), 979-1004. 
Glänzel, W., Debackere, K., Thijs, B., \& Schubert, A. (2006). A concise review on the role of author self-citations in information science, bibliometrics and science policy. Scientometrics, 67(2), 263-277.

Glynn, M. A., \& Raffaelli, R. (2010). Uncovering mechanisms of theory development in an academic field: Lessons from leadership research. The Academy of Management Annals, 4(1), 359-401.

Graen, G. B., \& Uhl-Bien, M. (1995). Relationship-based approach to leadership: Development of leader-member exchange (LMX) theory of leadership over 25 years: Applying a multi-level multi-domain perspective. The Leadership Quarterly, 6(2), 219-247.

Hammond, M., Clapp-Smith, R., \& Palanski, M. (2017). Beyond (just) the workplace: A theory of leader development across multiple domains. Academy of Management Review, 42(3), 481-498.

Hannah, S. T., Sumanth, J. J., Lester, P., \& Cavarretta, F. (2014). Debunking the false dichotomy of leadership idealism and pragmatism: Critical evaluation and support of newer genre leadership theories. Journal or Organizational Behavior, 35(5), 598-621.

Hoch, J.E., Bommer, W.H., Dulebohn, J.H., \& Wu, D. (2018). Do ethical, authentic, and servant leadership explain variance above and beyond transformational leadership? A meta-analysis. Journal of Management, 44(2), 501-529.

Hogg, M. A. (2001). A social identity theory of leadership. Personality and Social Psychology Review, 5(3), 184-200.

Hollenbeck, G. P., McCall, M. W., \& Silzer, R. F. (2006). Leadership competency models. Leadership Quarterly, 17(4), 398-413.

Huff, A.S. (1999). Writing for scholarly publication. Thousand Oaks: Sage. 
Janson, A. (2008). Extracting leadership knowledge from formative experiences. Leadership, 4(1), 73-94.

Judge, T. A., Bono, J. E., Ilies, R., \& Gerhardt, M. W. (2002). Personality and leadership: A qualitative and quantitative review. Journal of Applied Psychology, 87(4), 765-780.

Kanfer, R., \& Ackerman, P. L. (1989). Motivation and cognitive abilities: An integrative/aptitude-treatment interaction approach to skill acquisition. Journal of Applied Psychology, 74(4), 657-690.

Kark, R. (2011). Games managers play: Play as a form of leadership development. Academy of Management Learning \& Education, 10(3), 507-527.

Kessler, M. M. (1963). Bibliographic coupling between scientific papers. Journal of the Association for Information Science and Technology, 14(1), 10-25.

Klimoski, R., \& Amos, B. (2012). Practicing evidence-based education in leadership development. Academy of Management Learning \& Education, 11(4), 685-702.

Kluger, A. N., \& DeNisi, A. (1996). The effects of feedback interventions on performance: A historical review, a meta-analysis, and a preliminary feedback intervention theory. Psychological Bulletin, 119(2), 254-284.

Kolb, D. A. (1984). Experiential learning: Experience as thesource of learning and development. Englewood Cliffs, NJ: Prentice Hall.

Lacerenza, C. N., Reyes, D. L., Marlow, S. L., Joseph, D. L., \& Salas, E. (2017). Leadership training design, delivery, and implementation: A meta-analysis. Journal of Applied Psychology, 102(12), 1686-1718.

Latham, G. P., \& Frayne, C. A. (1989). Self-management training for increasing job attendance: A follow-up and a replication. Journal of Applied Psychology, 74(3), 411416. 
Le, H., Oh, I.-S., Robbins, S. B., Ilies, R., Holland, E., \& Westrick, P. (2011). Too much of a good thing: Curvilinear relationships between personality traits and job performance. Journal of Applied Psychology, 96(1), 113-133.

Lester, P. B., Hannah, S. T., Harms, P. D., Vogelgesang, G. R., \& Avolio, B. J. (2011). Mentoring impact on leader efficacy development: A field experiment. Academy of Management Learning \& Education, 10(3), 409-429.

Li, W.-D., Arvey, R. D., \& Song, Z. (2011). The influence of general mental ability, selfesteem and family socioeconomic status on leadership role occupancy and leader advancement: The moderating role of gender. The Leadership Quarterly, 22(3), 520534.

Ligon, G. S., Hunter, S. T., \& Mumford, M. D. (2008). Development of outstanding leadership: A life narrative approach. The Leadership Quarterly, 19(3), 312-334.

Liu, J. S., Lu, L. Y., Lu, W. M., \& Lin, B. J. (2013). Data envelopment analysis 1978-2010: A citation-based literature survey. Omega, 41(1), 3-15.

Locke, E. A., \& Latham, G. P. (1990). A theory of goal setting \& task performance. Englewood Cliffs, NJ: Prentice-Hall, Inc.

Lord, R. G., Foti, R. J., \& de Vader, C. L. (1984). A test of leadership categorization theory: Internal structure, information processing, and leadership perceptions. Organizational Behavior \& Human Performance, 34(3), 343-378.

Lord, R. G. \& Hall, R. J. (2005). Identity, deep structure and the development of leadership skill. The Leadership Quarterly, 16(4), 591-615.

Lyness, K. S., \& Grotto, A. R. (2018). Women and leadership in the United States: Are we closing the gender gap? The Annual Review of Organizational Psychology and Organizational Behavior, 5, 227-265. 
Mabey, C. (2013). Leadership development in organizations: Multiple discourses and diverse practice. International Journal of Management Reviews, 15, 359-380.

Maurer, T. J., Barbeite, F. G., \& Mitchell, D. R. D. (2002). Predictors of attitudes toward a 360-degree feedback system and involvement in post-feedback management development activity. Journal of Occupational \& Organizational Psychology, 75(1), 87-107.

McAlearney, A. S. (2006). Leadership development in healthcare: a qualitative study. Journal of Organizational Behavior, 27(7), 967-982.

McCain, K. W. (1990). Mapping authors in intellectual space: A technical overview. Journal of the American Society for Information Science, 41(6), 433-443.

McCall, M. W. (2004). Leadership development through experience. Academy of Management Executive, 18(3), 127-130.

McCall, M. W., Jr. (2010). Recasting leadership development. Industrial and Organizational Psychology: Perspectives on Science and Practice, 3(1), 3-19.

McCall, M. W., Lombardo, M. M., \& Morrison, A. M. (1988). The lessons of experience: How successful executives develop on the job. Lexington, Mass: Lexington Books.

McCauley, C. D., Ruderman, M. N., Ohlott, P. J., \& Morrow, J. E. (1994). Assessing the developmental components of managerial jobs. Journal of Applied Psychology, 79(4), $544-560$.

McClean, S. T., Barnes, C. M., Courtright, S. H., \& Johnson, R. E. (2019). Resetting the Clock on Dynamic Leader Behaviors: A Conceptual Integration and Agenda for Future Research. Academy of Management Annals, 13(2), 479-508.

Menges, J., Walter, F. H., Vogel, B., \& Bruch, H. (2011). Transformational leadership climate: Performance linkages, mechanisms, and boundary conditions at the organizational level. The Leadership Quarterly, 22, 893-909. 
Meuser, J. D., Gardner, W. L., Dinh, J. E., Hu, J., Liden, R. C., \& Lord, R. G. (2016). A network analysis of leadership theory. Journal of Management, 42(5), 1374-1403.

Middleton, E.D., Walker, D.O., \& Reichard, R.J. (2019). Developmental trajectories of leader identity: Role of learning goal orientation. Journal of Leadership \& Organizational Studies, 26(4), 495-509.

Miscenko, D., Guenter, H., \& Day, D.V. (2017). Am I a leader? Examining leader identity development over time. The Leadership Quarterly, 28, 605-620.

Mumford, T. V., Campion, M. A., \& Morgeson, F. P. (2007). The leadership skills strataplex: Leadership skill requirements across organizational levels. The Leadership Quarterly, $18(2), 154-166$.

Mumford, M. D., Marks, M. A., Connelly, M. S., Zaccaro, S. J., \& Reiter-Palmon, R. (2000). Development of leadership skills: Experience and timing. Leadership Quarterly, 11(1), 87 .

Murphy, S. E., \& Johnson, S. K. (2011). The benefits of a long-lens approach to leader development: Understanding the seeds of leadership. The Leadership Quarterly, 22(3), 459-470.

Noe, R. A. (1986). Trainees' attributes and attitudes: Neglected influences on training effectiveness. The Academy of Management Review, 11(4), 736-749.

O'Connell, P. K. (2014). A simplified framework for 21 st century leader development. The Leadership Quarterly, 25(2), 183-203.

Pierce, J. R., \& Aguinis, H. (2013). The too-much-of-a-good-thing effect in management. Journal of Management, 39(2), 313-338.

Porter, L.W. \& Schneider, B. (2014). What was, what is, and what may be in OP/OB. Annual Review of Organizational Psychology and Organizational Behavior, 1, 1-21. 
Reichard, R. J., \& Johnson, S. K. (2011). Leader self-development as organizational strategy. The Leadership Quarterly, 22(1), 33-42.

Rhodes, C., \& Brundrett, M. (2009). Leadership development and school improvement. Educational Review, 61(4), 361-374.

Roberson, Q. (2019). Diversity in the workplace: A review, synthesis, and future research agenda. Annual Review of Organizational Psychology and Organizational Behavior, 6, 69-88.

Schyns, B., Kiefer, T., Kerschreiter, R., \& Tymon, A. (2011). Teaching implicit leadership theories to develop leaders and leadership: How and why it can make a difference. Academy of Management Learning \& Education, 10(3), 397-408.

Schyns, B. \& Meindl, J. R. (2005). An overview of implicit leadership theories and their application in organization practice, In B. Schyns \& J. R. Meindl (Eds.), Implicit leadership theories: Essays and explorations (pp. 15-36). Greenwich, CT: Information Age Publishing.

Seidman, S. (1983). Network structure and minimum degree. Social Networks, 5(3), 269 287.

Shamir, B. \& Eilam, G. (2005). "What's your story?" A life-stories approach to authentic leadership development. The Leadership Quarterly, 16, 395-417.

Shamir, B., House, R. J., \& Arthur, M. B. (1993). The motivational effects of charismatic leadership: A self-concept based theory. Organization Science, 4(4), 577-594.

Sinclair, A. (2009). Seducing Leadership: Stories of Leadership Development. Gender, Work \& Organization, 16(2), 266-284.

Small, H. (1973). Co-citation in the scientific literature: A new measure of the relationship between two documents. Journal of the Association for Information Science and Technology, 24(4), 265-269. 
Spreitzer, G. M. (2006). Leading to grow and growing to lead: Leadership development lessons from positive organizational studies. Organizational Dynamics, 35(4), 305315.

Training Industry. (April 23, 2019). Size of the Training Industry. Retrieved from https://trainingindustry.com/wiki/outsourcing/size-of-training-industry/

Tsang, E. W., \& Frey, B. S. (2007). The As-Is Journal Review Process: Let Authors Own Their Ideas. Academy of Management Learning \& Education, 6(1), 128-136.

Tsui, A. S. (2013). The spirit of science and socially responsible scholarship. Management and Organization Review, 9(3), 375-394.

Uhl-Bien, M., Marin, R., \& McKelvey, B. (2007). Complexity Leadership Theory: Shifting leadership from the industrial age to the knowledge era. The Leadership Quarterly, 18(4), 298-318.

Uhl-Bien, M. (2006). Relational leadership theory: Exploring the social processes of leadership and organizing. The Leadership Quarterly, 17(6), 654-676.

van Eck, N. J., \& Waltman, L. (2014a). CitNetExplorer: A new software tool for analyzing and visualizing citation networks. Journal of Informetrics, 8(4), 802-823.

van Eck, N. J., \& Waltman, L. (2014b). Visualizing bibliometric networks Measuring scholarly impact (pp. 285-320): Springer.

van Eck, N. J., Waltman, L., Dekker, R., \& van den Berg, J. (2010). A comparison of two techniques for bibliometric mapping: Multidimensional scaling and VOS. Journal of the American Society for Information Science and Technology, 61(12), 2405-2416.

van Knippenberg, D., van Knippenberg, B., De Cremer, D., \& Hogg, M. A. (2004). Leadership, self, and identity: A review and research agenda. The Leadership Quarterly, 15(6), 825-856. 
van Raan, A. (1996). Advanced bibliometric methods as quantitative core of peer review based evaluation and foresight exercises. Scientometrics, 36(3), 397-420.

Van Raan, A. (2005). For your citations only? Hot topics in bibliometric analysis. Measurement: interdisciplinary research and perspectives, 3(1), 50-62.

Vogel, R. (2012). The Visible Colleges of Management and Organization Studies: A Bibliometric Analysis of Academic Journals. Organization Studies, 33(8), 1015-1043.

Vogel, B. (2017). Experiencing human energy as a catalyst for developing leadership capacity. In Koonce, R., Robinson, P. \& Vogel, B. (Eds.) Developing Leaders for Positive Organizing: A 21st century repertoire for leading in extraordinary times (pp. 275-306). Bingley: Emerald.

Wallin, J. A. (2005). Bibliometric methods: pitfalls and possibilities. Basic \& clinical pharmacology \& toxicology, 97(5), 261-275.

Walumbwa, F. O., Avolio, B. J., Gardner, W. L., Wernsing, T. S., \& Peterson, S. J. (2008). Authentic leadership: Development and validation of a theory-based measure. Journal of Manangement, 34(1), 89-126.

Wen, B., Horlings, E., van der Zouwen, M., \& van den Besselaar, P. (2017). Mapping science through bibliometric triangulation: An experimental approach applied to water research. Journal of the Association for Information Science and Technology, 68(3), 724-738.

Wolfgang, G., Bart, T., \& Balázs, S. (2004). A bibliometric approach to the role of author self-citations in scientific communication. Scientometrics, 59(1), 63-77.

Yip, J., Trainor, L., Black, H., Soto, L., \& Reichard, R.J. (in press). Coaching new leaders: A relational process of integrating multiple identities. Academy of Management Learning \& Education. 
Zupic, I., \& Čater, T. (2015). Bibliometric Methods in Management and Organization.

Organizational Research Methods, 18(3), 429-472. 
Figure 1: Citation network of the evolution of the leadership development field (based on historiography)

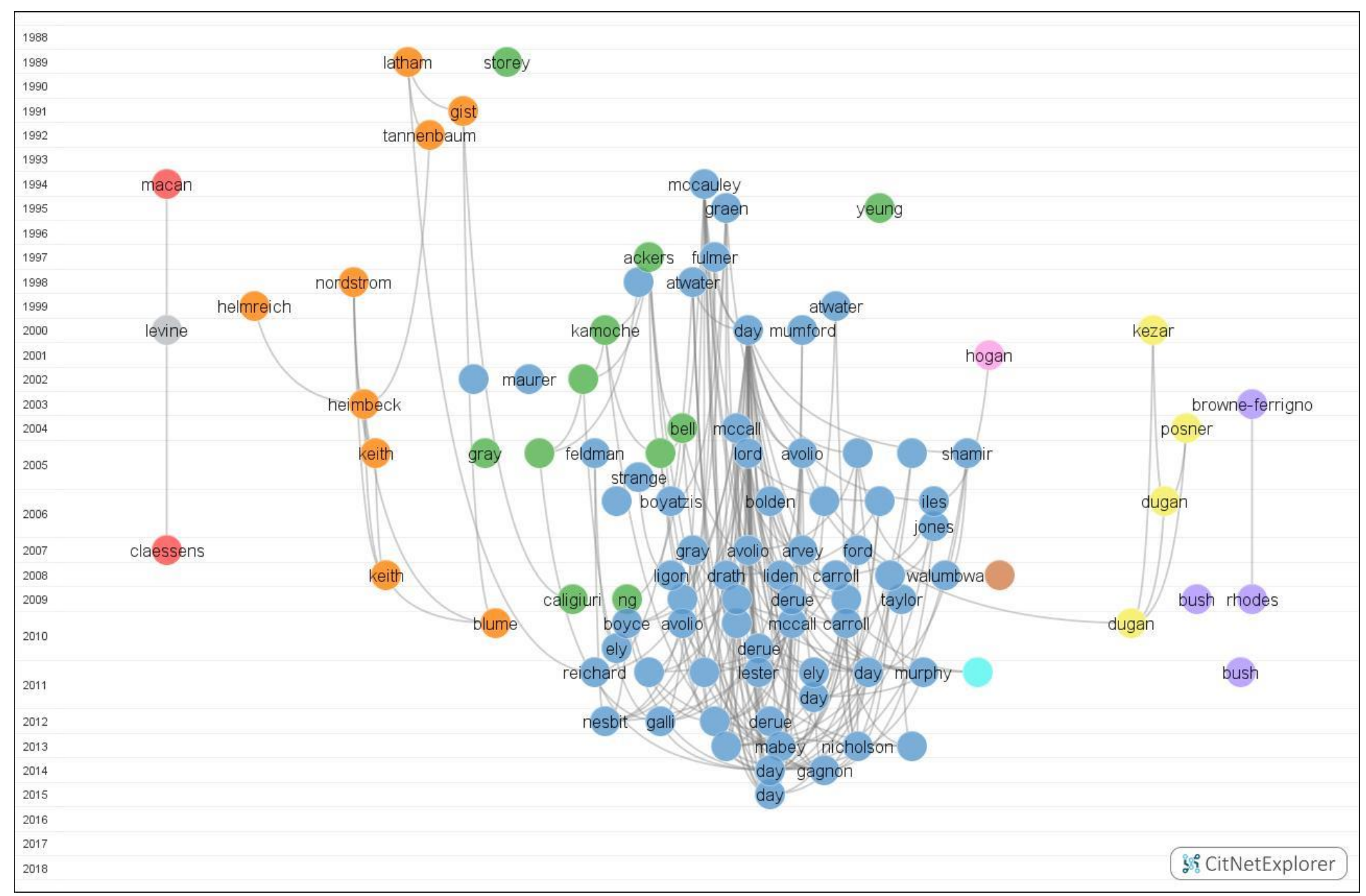

Note: Curved lines are used to indicate citation relations. Different shades represent the cluster to which primary papers have been assigned.

Clusters represent closely related papers, sharing thematic similarities. Include cluster $1=$ blue etc. ? 
Figure 2: The network containing 100 most important secondary papers and three clusters (based on co-citation analysis)

$$
\text { ely:2011 Cluster } 3 \text { (blue) }
$$

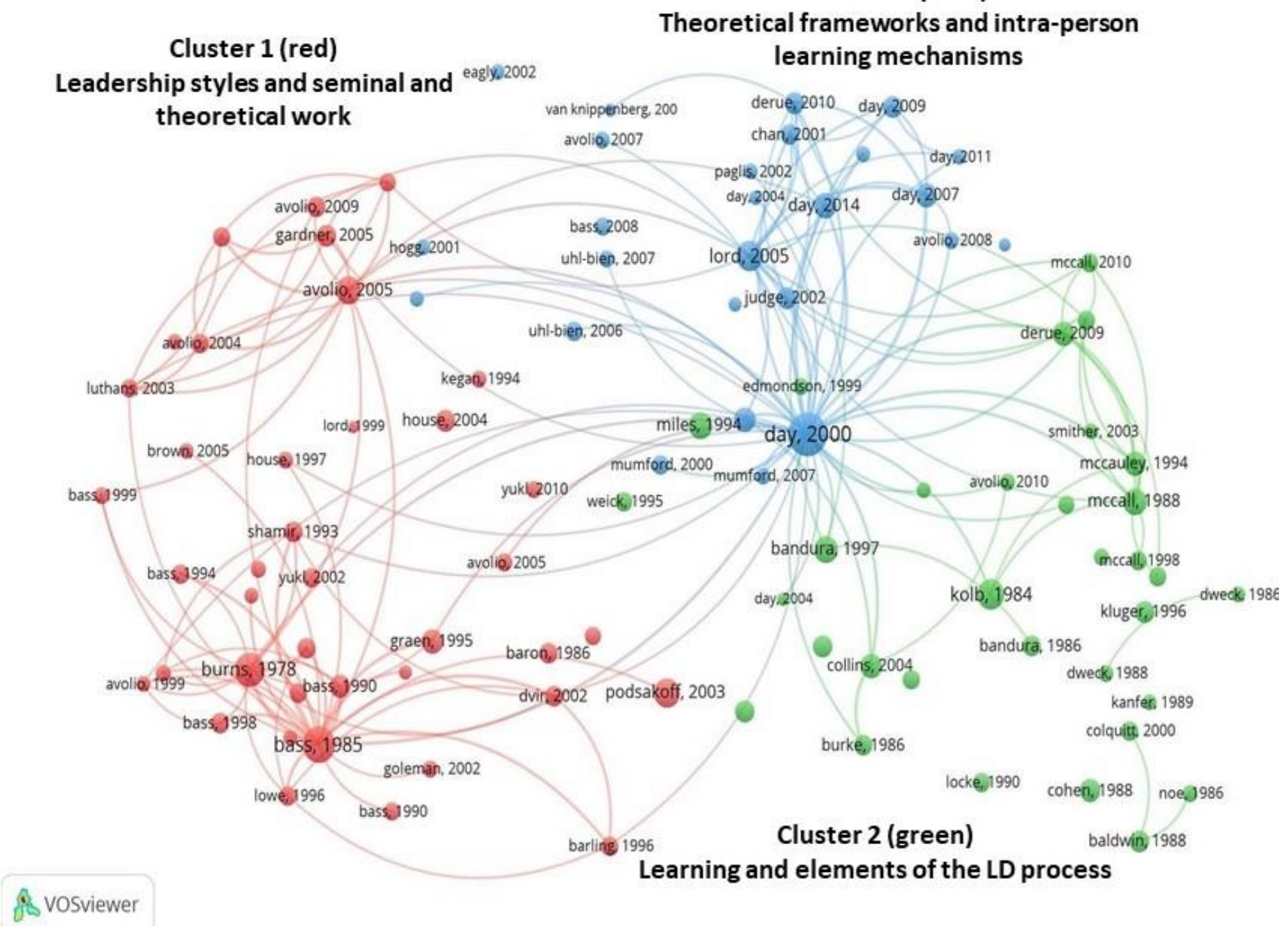

Note: Different colors are used to indicate the cluster to which a secondary paper has been assigned. The clusters represent closely related papers, which share thematic similarities. 
Figure 3: Research front (current state) of the leadership development field (based on bibliographic coupling)

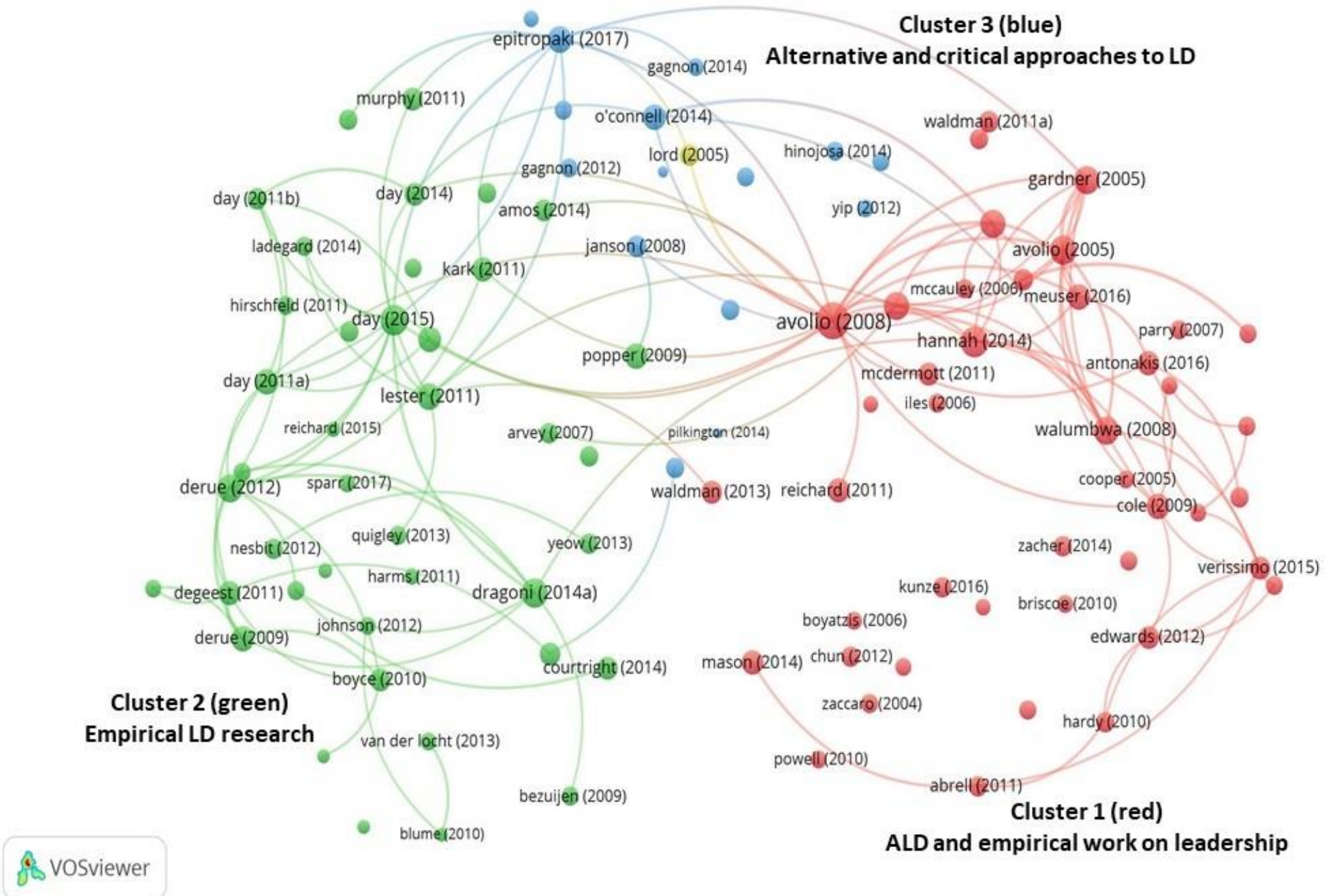

Note: Different colors are used to indicate the cluster to which a secondary paper has been assigned. The clusters represent closely related papers, which share thematic similarities. ALD = Authentic leadership development 
Table 1. Overview of three bibliometric techniques

\begin{tabular}{|c|c|c|c|}
\hline & Historiography & $\begin{array}{l}\text { Document Co- } \\
\text { citation }\end{array}$ & $\begin{array}{l}\text { Bibliographic } \\
\text { Coupling }\end{array}$ \\
\hline Focal point & $\begin{array}{l}\text { Primary (citing) } \\
\text { documents and their } \\
\text { chronological citations } \\
\text { with other cited } \\
\text { primary documents }\end{array}$ & $\begin{array}{l}\text { Secondary (cited) } \\
\text { documents being } \\
\text { cited together in } \\
\text { primary documents }\end{array}$ & $\begin{array}{l}\text { Primary (citing) } \\
\text { documents that cite the } \\
\text { same secondary } \\
\text { documents }\end{array}$ \\
\hline $\begin{array}{l}\text { Temporal } \\
\text { focus }\end{array}$ & $\begin{array}{l}\text { Past (field } \\
\text { development/evolution) }\end{array}$ & $\begin{array}{l}\text { Past (intellectual } \\
\text { structure; theoretical } \\
\text { foundations) }\end{array}$ & $\begin{array}{l}\text { Present/future } \\
\text { (research front, } \\
\text { emergent topics) }\end{array}$ \\
\hline $\begin{array}{l}\text { Time } \\
\text { sensitivity }\end{array}$ & No & Yes & No \\
\hline $\begin{array}{l}\text { Unique } \\
\text { components }\end{array}$ & $\begin{array}{l}\text { Shows the evolution } \\
\text { and dynamics of the } \\
\text { LD field and changes } \\
\text { of perceptions over } \\
\text { time }\end{array}$ & $\begin{array}{l}\text { Analyzes the roots of } \\
\text { the LD field and } \\
\text { "invisible colleges" } \\
\text { of authors being cited } \\
\text { together in clusters }\end{array}$ & $\begin{array}{l}\text { Detects current trends } \\
\text { and future priorities in } \\
\text { the LD field by } \\
\text { examining recent work }\end{array}$ \\
\hline $\begin{array}{l}\text { Key } \\
\text { methodological } \\
\text { mechanism }\end{array}$ & $\begin{array}{l}\text { How frequently a } \\
\text { primary document cites } \\
\text { another primary } \\
\text { document in its } \\
\text { reference list. } \\
\text { Knowledge flows from } \\
\text { the cited work to the } \\
\text { citing one, creating a } \\
\text { link between them. }\end{array}$ & $\begin{array}{l}\text { How frequently two } \\
\text { documents in the LD } \\
\text { field are cited by } \\
\text { another document } \\
\text { together. The more } \\
\text { two documents are } \\
\text { cited together, the } \\
\text { more likely it is that } \\
\text { their content is } \\
\text { related. }\end{array}$ & $\begin{array}{l}\text { How frequently two } \\
\text { documents cite the } \\
\text { same references. } \\
\text { Overlapping } \\
\text { bibliographies indicate } \\
\text { stronger similarity } \\
\text { between the } \\
\text { documents. }\end{array}$ \\
\hline $\begin{array}{l}\text { Indicator of } \\
\text { document } \\
\text { strength/ } \\
\text { weight }\end{array}$ & $\begin{array}{l}\text { "Core" documents = } \\
\text { frequency of citations } \\
\text { of a primary document } \\
\text { from other primary } \\
\text { documents }\end{array}$ & $\begin{array}{l}\text { Co-citation strength = } \\
\text { the frequency with } \\
\text { which two secondary } \\
\text { documents are co- } \\
\text { cited by primary } \\
\text { documents }\end{array}$ & $\begin{array}{l}\text { Coupling strength }= \\
\text { frequency co- } \\
\text { occurrence of } \\
\text { secondary documents } \\
\text { in the reference list of } \\
\text { two primary documents }\end{array}$ \\
\hline $\begin{array}{l}\text { Research } \\
\text { Question } \\
\text { Addressed }\end{array}$ & $\begin{array}{l}\text { How has the } \\
\text { knowledge domain of } \\
\text { LD evolved over time? }\end{array}$ & $\begin{array}{l}\text { What is the } \\
\text { underlying } \\
\text { intellectual structure } \\
\text { in the knowledge } \\
\text { domain of LD? }\end{array}$ & $\begin{array}{l}\text { Considering the paths, } \\
\text { strengths, and gap in } \\
\text { the structure and } \\
\text { evolution of LD } \\
\text { research, what are the } \\
\text { theoretically and } \\
\text { practically relevant } \\
\text { future directions for } \\
\text { research in LD? }\end{array}$ \\
\hline
\end{tabular}


Table 2

Document Co-Citation: Overview by Cluster

\begin{tabular}{|c|c|c|c|c|c|c|c|c|c|}
\hline Sample & $N$ & $\begin{array}{c}\text { Year of } \\
\text { Publication }\end{array}$ & $\begin{array}{c}\text { Type of } \\
\text { Publication }\end{array}$ & Topic & $\begin{array}{c}\text { Leadership } \\
\text { Theory }\end{array}$ & $\begin{array}{l}\text { Document } \\
\text { Orientation }\end{array}$ & $\begin{array}{l}\text { Type of } \\
\text { Paper }\end{array}$ & $\begin{array}{l}\text { Level of } \\
\text { Analysis }\end{array}$ & Level Type \\
\hline Overall & 100 & $\begin{array}{c}2001-2010 \\
(47.0 \%)\end{array}$ & $\begin{array}{c}\text { Book } \\
(35.0 \%)\end{array}$ & $\begin{array}{c}\text { Leadership } \\
(44.0 \%)\end{array}$ & $\begin{array}{c}\text { TFL } \\
(25.0 \%)\end{array}$ & $\begin{array}{c}\text { Basic } \\
(78.0 \%)\end{array}$ & $\begin{array}{c}\text { Theoretical } \\
(41.0 \%)\end{array}$ & $\begin{array}{c}\text { Multiple } \\
(61.0 \%)\end{array}$ & $\begin{array}{c}\text { Micro } \\
(41.0 \%)\end{array}$ \\
\hline $\begin{array}{l}\text { Cluster } 1 \\
\text { (Red) }\end{array}$ & 40 & $\begin{array}{c}2001-2010 \\
(45.0 \%)\end{array}$ & $\begin{array}{c}\text { Book } \\
(42.5 \%)\end{array}$ & $\begin{array}{c}\text { Leadership } \\
(70.0 \%)\end{array}$ & $\begin{array}{c}\text { TFL } \\
(17.5 \%)\end{array}$ & $\begin{array}{c}\text { Basic } \\
(87.5 \%)\end{array}$ & $\begin{array}{c}\text { Theoretical } \\
(42.5 \%)\end{array}$ & $\begin{array}{l}\text { Multiple } \\
(75.0 \%)\end{array}$ & $\begin{array}{l}\text { Micro, } \\
\text { Meso, } \\
\text { Macro } \\
(35.0 \%)\end{array}$ \\
\hline $\begin{array}{l}\text { Cluster } 2 \\
\text { (Green) }\end{array}$ & 33 & $\begin{array}{c}1981-1990 \\
(33.3 \%)\end{array}$ & $\begin{array}{c}\text { Book } \\
(48.5 \%)\end{array}$ & $\begin{array}{c}\text { Non- } \\
\text { Leadership } \\
(60.6 \%)\end{array}$ & N/A & $\begin{array}{c}\text { Basic } \\
(57.6 \%)\end{array}$ & $\begin{array}{c}\text { Theoretical } \\
(33.3 \%)\end{array}$ & $\begin{array}{l}\text { Multiple } \\
(42.4 \%)\end{array}$ & $\begin{array}{c}\text { Micro } \\
(48.5 \%)\end{array}$ \\
\hline $\begin{array}{l}\text { Cluster } 3 \\
\text { (Blue) }\end{array}$ & 27 & $\begin{array}{c}2001-2010 \\
(70.4 \%)\end{array}$ & LQ (44.4\%) & $\begin{array}{l}\text { Leadership } \\
(59.3 \%)\end{array}$ & LMX (7.4\%) & $\begin{array}{c}\text { Basic } \\
(88.9 \%)\end{array}$ & $\begin{array}{c}\text { Theoretical } \\
(48.1 \%)\end{array}$ & $\begin{array}{c}\text { Multiple } \\
(63.0 \%)\end{array}$ & $\begin{array}{l}\text { Micro, } \\
\text { Meso, } \\
\text { Macro } \\
(44.4 \%)\end{array}$ \\
\hline
\end{tabular}

Note. $\mathrm{LD}=$ Leader/ship Development; LQ = Leadership Quarterly; TFL = Transformational Leadership; LMX = Leader-Member Exchange. 
Table 3

Top 5 most important documents for each cluster in the co-citation analysis

\begin{tabular}{|c|c|c|c|}
\hline Cluster & Author and Year & Document Description & Weight \\
\hline \multirow{5}{*}{$\begin{array}{l}\text { Seminal, mostly } \\
\text { conceptual and } \\
\text { leadership styles } \\
\text { focused work on } \\
\text { charismatic, } \\
\text { transformational, } \\
\text { and authentic } \\
\text { leadership } \\
\text { (Cluster } 1 \text { red) }\end{array}$} & Bass (1985) & $\begin{array}{l}\text { A classic book on leadership theory that } \\
\text { discusses individual-level predictors and } \\
\text { outcomes }\end{array}$ & 717 \\
\hline & Burns (1978) & $\begin{array}{l}\text { A classic book on leadership theory that } \\
\text { discusses multi-level predictors and } \\
\text { outcomes }\end{array}$ & 489 \\
\hline & $\begin{array}{l}\text { Avolio \& } \\
\text { Gardner (2005) }\end{array}$ & $\begin{array}{l}\text { Original review article establishing the } \\
\text { framework of authentic leadership } \\
\text { development }\end{array}$ & 448 \\
\hline & $\begin{array}{l}\text { Shamir, House, } \\
\text { \& Arthur (1993) }\end{array}$ & $\begin{array}{l}\text { A theoretical article that proposes a model } \\
\text { explaining the process of how charismatic } \\
\text { leadership impacts followers }\end{array}$ & 347 \\
\hline & $\begin{array}{l}\text { Dvir, Eden, } \\
\text { Avolio, \& } \\
\text { Shamir (2002) }\end{array}$ & $\begin{array}{l}\text { Longitudinal field experiment examining the } \\
\text { effects of transformational leadership } \\
\text { training on follower development and } \\
\text { performance in a military setting }\end{array}$ & 336 \\
\hline \multirow{5}{*}{$\begin{array}{l}\text { Developmental } \\
\text { interventions } \\
\text { emphasizing } \\
\text { experience and } \\
\text { other facets of } \\
\text { the leadership } \\
\text { development } \\
\text { process (Cluster } \\
2 \text { green) }\end{array}$} & $\begin{array}{l}\text { DeRue \& } \\
\text { Wellman (2009) }\end{array}$ & $\begin{array}{l}\text { A longitudinal study assessing the impact of } \\
\text { experience, context, and individual } \\
\text { differences on leadership skill development } \\
\text { at work }\end{array}$ & 415 \\
\hline & $\begin{array}{l}\text { McCauley, } \\
\text { Ruderman, } \\
\text { Ohlott, \& } \\
\text { Morrow (1994) }\end{array}$ & $\begin{array}{l}\text { Scale development for the Developmental } \\
\text { Challenge Profile }\end{array}$ & 343 \\
\hline & Bandura (1997) & $\begin{array}{l}\text { Seminal book reviewing empirical support } \\
\text { on the positive relationship between self- } \\
\text { efficacy and intrapersonal outcomes. }\end{array}$ & 338 \\
\hline & $\begin{array}{l}\text { Collins \& Holton } \\
(2004)\end{array}$ & $\begin{array}{l}\text { A meta-analysis on the relationship between } \\
\text { formal training interventions and multi-level } \\
\text { performance, knowledge, and expertise }\end{array}$ & 337 \\
\hline & $\begin{array}{l}\text { McCall, } \\
\text { Lombardo, \& } \\
\text { Morrison (1988) }\end{array}$ & $\begin{array}{l}\text { A book that uses anecdotal evidence to } \\
\text { illustrate how to learn and develop from } \\
\text { work experiences }\end{array}$ & 330 \\
\hline
\end{tabular}




\begin{tabular}{|c|c|c|c|}
\hline \multirow{5}{*}{$\begin{array}{l}\text { Theoretical } \\
\text { frameworks and } \\
\text { specific, intra- } \\
\text { person learning } \\
\text { mechanisms } \\
\text { such as identity } \\
\text { (Cluster } 3 \text { blue) }\end{array}$} & Day (2000) & $\begin{array}{l}\text { Review article that clarifies the distinction } \\
\text { between leader and leadership development, } \\
\text { and summarizes existing literature on } \\
\text { developmental practices }\end{array}$ & 1002 \\
\hline & $\begin{array}{l}\text { Lord \& Hall } \\
(2005)\end{array}$ & $\begin{array}{l}\text { Theoretical article proposing that identity, } \\
\text { meta-cognitive processes, and emotional } \\
\text { regulations are key factors in developing } \\
\text { leadership skills }\end{array}$ & 632 \\
\hline & $\begin{array}{l}\text { Day \& Harrison } \\
(2007)\end{array}$ & $\begin{array}{l}\text { A theoretical article that discusses the role of } \\
\text { identity in LD across multiple levels of } \\
\text { analyses }\end{array}$ & 434 \\
\hline & $\begin{array}{l}\text { Avolio, } \\
\text { Reichard, } \\
\text { Hannah, } \\
\text { Walumbwa, \& } \\
\text { Chan (2009) }\end{array}$ & $\begin{array}{l}\text { A meta-analysis on the effects of leadership } \\
\text { interventions }\end{array}$ & 391 \\
\hline & $\begin{array}{l}\text { DeRue \& } \\
\text { Ashford (2010) }\end{array}$ & $\begin{array}{l}\text { A prescriptive article that discusses the co- } \\
\text { construction of leader identity via social } \\
\text { processes of claiming and granting }\end{array}$ & 374 \\
\hline
\end{tabular}

Note: The weight column shows the total strength of the links of an item with other items. In this case, the weight indicates the total strength of the co-citations links of a given document with other documents. In general, the higher the weight, the more important a document is to the network 
Table 4

Bibliographic Coupling: Overview by Cluster

\begin{tabular}{|c|c|c|c|c|c|c|c|c|c|}
\hline Sample & $N$ & $\begin{array}{c}\text { Year of } \\
\text { Publication }\end{array}$ & $\begin{array}{c}\text { Type of } \\
\text { Publication }\end{array}$ & Topic & $\begin{array}{c}\text { Leadership } \\
\text { Theory }\end{array}$ & $\begin{array}{l}\text { Document } \\
\text { Orientation }\end{array}$ & $\begin{array}{l}\text { Type of } \\
\text { Paper }\end{array}$ & $\begin{array}{l}\text { Level of } \\
\text { Analysis }\end{array}$ & Level Type \\
\hline Overall & 100 & $\begin{array}{l}2011-2015 \\
(59.0 \%)\end{array}$ & LQ $(50.0 \%)$ & $\begin{array}{c}\text { LD } \\
(61.0 \%)\end{array}$ & $\begin{array}{c}\text { TFL } \\
(37.5 \%)\end{array}$ & $\begin{array}{c}\text { Basic } \\
(53.0 \%)\end{array}$ & $\begin{array}{c}\text { Quantitative } \\
(33.0 \%)\end{array}$ & $\begin{array}{l}\text { Multiple } \\
(36.0 \%)\end{array}$ & $\begin{array}{c}\text { Micro } \\
(65.0 \%)\end{array}$ \\
\hline $\begin{array}{l}\text { Cluster } 1 \\
\text { (Red) }\end{array}$ & 43 & $\begin{array}{l}2011-2015 \\
(39.5 \%)\end{array}$ & LQ $(27.9 \%)$ & $\begin{array}{l}\text { Leadership } \\
(62.8 \%)\end{array}$ & $\begin{array}{c}\text { TFL } \\
(18.2 \%)\end{array}$ & $\begin{array}{c}\text { Basic } \\
(53.5 \%)\end{array}$ & $\begin{array}{c}\text { Quantitative } \\
(32.6 \%)\end{array}$ & $\begin{array}{l}\text { Multiple } \\
(46.5 \%)\end{array}$ & $\begin{array}{c}\text { Micro } \\
(60.5 \%)\end{array}$ \\
\hline $\begin{array}{l}\text { Cluster } 2 \\
\text { (Green) }\end{array}$ & 41 & $\begin{array}{l}2011-2015 \\
(70.8 \%)\end{array}$ & LQ (31.7\%) & $\begin{array}{c}\text { LD } \\
(82.9 \%)\end{array}$ & $\operatorname{LMX}(4.9 \%)$ & $\begin{array}{l}\text { Applied } \\
(53.7 \%)\end{array}$ & $\begin{array}{c}\text { Quantitative } \\
(46.3 \%)\end{array}$ & $\begin{array}{c}\text { One } \\
(39.0 \%)\end{array}$ & $\begin{array}{c}\text { Micro } \\
(73.2 \%)\end{array}$ \\
\hline $\begin{array}{l}\text { Cluster } 3 \\
\text { (Blue) }\end{array}$ & 15 & $\begin{array}{c}2011-2015 \\
(86.6 \%)\end{array}$ & LQ (66.7\%) & $\begin{array}{c}\text { LD } \\
(66.7 \%)\end{array}$ & N/A & $\begin{array}{c}\text { Basic } \\
(73.3 \%)\end{array}$ & $\begin{array}{c}\text { Theoretical } \\
(26.7 \%)\end{array}$ & $\begin{array}{c}\text { Multiple } \\
(40.0 \%)\end{array}$ & $\begin{array}{c}\text { Micro } \\
(53.3 \%)\end{array}$ \\
\hline
\end{tabular}

Note. LD = Leader/ship Development; LQ = Leadership Quarterly; TFL = Transformational Leadership; LMX = Leader-Member Exchange. 
Table 5

Top 5 most important documents for each cluster in the bibliographic coupling analysis

\begin{tabular}{|c|c|c|c|}
\hline Cluster & Document Citation & Document Description & Weight \\
\hline \multirow{5}{*}{$\begin{array}{l}\text { Authentic } \\
\text { leadership } \\
\text { development } \\
\text { and empirical } \\
\text { work on (non- } \\
\text { developmental) } \\
\text { leadership } \\
\text { (Cluster } 1 \text { red) }\end{array}$} & $\begin{array}{l}\text { Avolio \& Chan } \\
\text { (2008) }\end{array}$ & $\begin{array}{l}\text { A book chapter that reviews } 80 \text { years of } \\
\text { research and theory on LD }\end{array}$ & 700 \\
\hline & $\begin{array}{l}\text { Hannah, Sumanth, } \\
\text { Lester, \& } \\
\text { Cavarretta (2014) }\end{array}$ & $\begin{array}{l}\text { A theoretical article that asserts the validity } \\
\text { and practical effectiveness of newer genre } \\
\text { leadership theories such as transformational, } \\
\text { ethical, and authentic }\end{array}$ & 492 \\
\hline & $\begin{array}{l}\text { Avolio \& Gardner } \\
(2005)\end{array}$ & $\begin{array}{l}\text { Original review article establishing the } \\
\text { framework of authentic leadership } \\
\text { development }\end{array}$ & 450 \\
\hline & $\begin{array}{l}\text { Gardner, Avolio, } \\
\text { Luthans, May, } \\
\text { Walumbwa (2005) }\end{array}$ & $\begin{array}{l}\text { A theoretical article that presents a model of } \\
\text { authentic leader and follower development }\end{array}$ & 423 \\
\hline & $\begin{array}{l}\text { Walumbwa, } \\
\text { Avolio, Gardner, } \\
\text { Wernsing, \& } \\
\text { Peterson (2008) }\end{array}$ & $\begin{array}{l}\text { Scale development article for the Authentic } \\
\text { Leadership Questionnaire }\end{array}$ & 410 \\
\hline
\end{tabular}

Day \& Dragoni (2015)

Empirical leadership development research largely micro in nature with movement toward longitudinal work (Cluster 2 green)
Dragoni, Oh, Tesluk, Moore, VanKatwyk, \& Hazucha (2014)

DeRue, Nahrgang, Hollenbeck, \& Workman (2012)

Lester, Hannah, Harms, Vogelgesang, \& Avolio (2011)
Review article describing proximal and distal LD outcomes at multiple levels of analysis 496 (individual and collective)

A quantitative study examining the relationship between leaders' global work experiences and strategic thinking competencies

A quantitative study examining the role of after-event reviews in leadership development

Longitudinal field experiment examining the impact of mentoring on leader development 
A longitudinal quantitative study assessing

Day \& Sin (2011) the roles of leader identity and goal orientation in leaders' developmental trajectories

Epitropaki, Kark, Mainemelis, \&

A multilevel review on the impact of identity Lord (2017) on leader and follower development

A theoretical article that proposes a

O'Connell (2014) framework for LD in complex contexts and

Alternative and environments

critical approaches to leadership development

Janson (2008) Mixed methods study testing the efficacy of (Cluster 3 blue)

Galli \& Muller-

Stewens (2012)

Mixed methods study examining the relationship between LD practices and social capital development

Edwards, Elliott, Iszatt-White, \& Schedlitzki (2013)

Review article on leadership learning and development

$\begin{array}{ll}\begin{array}{l}\text { A single article } \\ \text { on leader }\end{array} & \\ \text { identity } & \text { Lord \& Hall } \\ \text { development } & \text { (2005) } \\ \text { (Cluster } 4 & \\ \text { yellow) } & \end{array}$

Theoretical article proposing that identity, meta-cognitive processes, and emotional regulations are key factors in developing leadership skills

Note: The weight column shows the total strength of the links of an item with other items. In this case, the weight indicates the total strength of the coupling links of a given document with other documents. In general, the higher the weight, the more important a document is to the network. 
Table 6

Summary of Future Research Directions based on Results from Bibliometric Analyses

\begin{tabular}{|c|c|c|}
\hline $\begin{array}{l}\text { Research Direction } 1 \\
\text { Pursuing research within the } \\
\text { current framing of } \mathrm{LD}\end{array}$ & $\begin{array}{l}\text { Research Direction } 2 \\
\text { Striving for frame-breaking } \\
\text { LD research }\end{array}$ & $\begin{array}{l}\text { Research Direction } 3 \\
\text { How we get there - } \\
\text { Transforming LD } \\
\text { research }\end{array}$ \\
\hline $\begin{array}{l}\text { LD theories are proposed, yet } \\
\text { not comprehensively } \\
\text { investigated } \\
\text { - } \quad \text { Leader identity development } \\
\text { theory } \\
\text { - Authentic leadership } \\
\text { development theory }\end{array}$ & $\begin{array}{l}\text { Fostering LD research on } \\
\text { under- or unrepresented, } \\
\text { demographically diverse leaders } \\
\text { - } \quad \text { Women and LD } \\
\text { - } \quad \text { Racial minorities and LD } \\
\text { - } \quad \text { LGBTQ+ and LD }\end{array}$ & $\begin{array}{l}\text { Advancing research- } \\
\text { practice partnerships }\end{array}$ \\
\hline $\begin{array}{l}\text { A wide variety of contextual and } \\
\text { personal antecedents to LD are } \\
\text { independently discussed } \\
\text { - Relative impact of different } \\
\text { interventions / antecedents } \\
\text { - Ordering and sequencing } \\
\text { effects of interventions / } \\
\text { antecedents }\end{array}$ & $\begin{array}{l}\text { Researching detrimental aspects } \\
\text { of LD } \\
\text { - Negative consequences of } \\
\text { LD } \\
\text { - Decreasing utility, } \\
\text { trajectories and inflection } \\
\text { points of LD processes } \\
\text { - Trade-offs between } \\
\text { beneficial and detrimental } \\
\text { LD outcomes }\end{array}$ & $\begin{array}{l}\text { Exploring implicit } \\
\text { leadership development } \\
\text { theory }\end{array}$ \\
\hline $\begin{array}{l}\text { Unmet aspirations for } \\
\text { understanding multi-level } \\
\text { developmental outcomes and for } \\
\text { a temporal lens on LD } \\
\text { - Nuanced differentiation of } \\
\text { multi-level research and } \\
\text { integrating theory across } \\
\text { levels } \\
\text { - Timing of and time for } \\
\text { development }\end{array}$ & $\begin{array}{l}\text { Researching the role of affect in } \\
\text { LD } \\
\text { - } \quad \text { Role of negative versus } \\
\text { positive affect in } \\
\text { experience-based LD } \\
\text { - } \quad \text { Spill-over effects of positive } \\
\text { or negative affect from LD } \\
\text { initiatives into social } \\
\text { spheres beyond work }\end{array}$ & \\
\hline
\end{tabular}

